MICHAE TOMASZEK

https://orcid.org/0000-0001-5078-8068

Instytut Historii Uniwersytetu Marii Curie-Skłodowskiej

\title{
PENITENCJAE BISKUPA HALITGARA I KAROLIŃSKIE „PAŃSTWO STANU POKUTNEGO”
}

\begin{abstract}
Abstrakt: Artykuł pokazuje, jak w okresie panowania Karola Wielkiego i Ludwika Pobożnego biskupi we współpracy z władcami podjęli się zreformowania praktyk pokutnych. Omówione zostały okoliczności powstania penitencjału Halitgara oraz sposób, w jaki autor próbował obdarzyć tekst autorytetem. Przedstawiona została struktura dzieła i zawarte w nim zapisy. Wreszcie sformułowane zostały hipotezy dotyczące roli, jaką w rzeczywistości pełnił w Kościele karolińskim penitencjał Halitgara w pierwszych dziesięcioleciach po jego zredagowaniu.
\end{abstract}

Słowa kluczowe: penitencjały (libri poenitentiales), Karolingowie, episkopat karoliński, Karol Wielki, Ludwik Pobożny, Halitgar z Cambrai.
Abstract: In his article, the author presents how, during the reigns of Charlemagne and Louis the Pious, bishops in cooperation with rulers undertook the reform of penance. $\mathrm{He}$ discusses the circumstances in which the Penitentialis of Bishop Halitgar was compiled and ways in which the Bishop tried to bestow authority on it. Next, the structure of the penitential is presented together with its regulations. Finally, the article's author puts forwards his hypotheses on the actual role played by Halitgar's Penitential in the Carolingian Church during the first decades after its compilation.

Keyw ords: penitentials (libri poenitentiales), Carolingians, Carolingian episcopate, Charlemagne, Louis I the Pious, Halitgar of Cambrai.

Termin „państwo stanu pokutnego” (w oryginale Penitential State) to część tytułu opublikowanej przed kilku laty monografii Mayke de Jong ${ }^{1}$.

${ }^{1}$ M. de Jong, The Penitential State Authority and Atonement in the Age of Louis the Pious, 814-840, Cambridge 2009. Polską recenzję opublikowała Aneta Pieniądz w „Kwartalniku Historycznym" 118, 2011, 2, s. 323-328, która tłumaczy Penitential State jako państwo pokutnicze, co może jednak gubić pewien niuans. 
Holenderska uczona poświęciła swoją książkę pewnemu szczególnemu aspektowi panowania cesarza i władcy monarchii frankijskiej, Ludwika Pobożnego (814-840). W skrócie można rzecz nazwać wydatną obecnością $\mathrm{w}$ życiu publicznym rytuałów pokuty. Panowanie Ludwika naznaczyły spektakularne, dobrowolne bądź wymuszone, publiczne pokuty samego cesarza, członków jego rodziny oraz reprezentantów elity duchownej i świeckiej. Współczesne relacjom źródeł narracyjnych na temat poszczególnych ceremonii są teksty, które rozwijały ideowe podłoże owych działań. Pisane przez wpływowych biskupów i opatów, po części miały charakter oficjalnych kościelnych dokumentów. Wyrażały i uzasadniały przekonanie o konieczności ciągłego zabiegania o łaskę Boga poprzez uznawanie i wyznawanie swoich win, napominanie innych, okazywanie skruchy. Ustawiczna czujność w dziedzinie tropienia grzechu i pieczołowitość w należytym odbywaniu pokuty mogły, zgodnie $\mathrm{z}$ tą perspektywą, ułagodzić Stwórcę i zapewnić pokój². W tle rozwijały się - we wzajemnym powiązaniu - idee sumienia jako wewnętrznego sądu duszy, rachunku win, a także doktryna grzechów głównych (wtedy jeszcze zresztą ośmiu) $)^{3}$.

Jedno z pytań, które stawia się w badaniach nad epoką, dotyczy zakorzenienia owego postulowanego przez pasterzy karolińskiego Kościoła stanu ciągłej gotowości do pokuty także poza polityczną elitą. Czy biskupi pierwszej połowy IX w. realizowali program upowszechnienia praktyk pokutnych w całej chrześcijańskiej społeczności? Jakkolwiek sugerują to kanony synodów i zachowane statuty wydawane przez pojedynczych hierarchów, pojawiły się też dobrze umotywowane głosy wątpiące. Przedmiotem dyskusji stało się w tym kontekście w szczególności funkcjonowanie w codziennej praktyce frankijskiego Kościoła libri poenitentiales, ksiąg pokutnych, inaczej penitencjałów.

W ramach niniejszego artykułu przybliżone zostaną działania karolińskich biskupów związane z propagowaniem pokuty. W szczególności

${ }^{2}$ Jak pisała Mayke de Jong we wstępie, The Penitential State, s. 5: „Rather than a police state, we are dealing with a political elite that was markedly preoccupied with sin and salvation - their own, and those of the "Christian people» that made up the Frankish polity". Por. też C.M. Booker, Hypocrisy, Performativity, and the Carolingian Pursuit of Truth, „Early Medieval Europe” 26, 2018, 2, s. 200.

${ }^{3}$ Por. na ten temat m.in. A. Firey, Blushing before the Judge and Physician. Moral Arbitration in the Carolingian Empire, w: A New History of Penance, red. A. Firey, Leiden-Boston 2008, s. 173-200; C.M. Booker, Murmurs and Shouts. Speaking the Conscience in Carolingian Narratives, w: Produktivität einer Krise. Die Regierungszeit Ludwigs des Frommen (814-840) und die Transformation des karolingischen Imperium, red. P. Depreux, S. Esders, Ostfildern 2018, s. 343-358. Dla późniejszego niż tutaj omawiany okres por. m.in. J. Goering, The Internal Forum and the Literature of Penance and Confession, „Traditio” 59, 2004, s. 175-227. 
zaproponowana zostanie interpretacja powiązanych ze sobą bez wątpienia kroków kościelnych przywódców: werbalnego, jednoznacznego potępienia dotychczas stosowanych penitencjałów przez synody gromadzące reprezentantów karolińskiego episkopatu w 813 i 829 r. oraz próba zastąpienia potępionych tekstów przez dzieło autorstwa biskupa Cambrai Halitgara, którego to traktatu częścią był penitencjał odnaleziony, wedle deklaracji Halitgara, w archiwum rzymskiego Kościoła.

Tezą, którą poniżej spróbuję uzasadniać, jest twierdzenie, że nadrzędny cel poczynań niektórych karolińskich biskupów stanowiła standaryzacja praktyk i poddanie ściślejszej kontroli kościelnej władzy pokuty we wszystkich jej wymiarach: wyznanie grzechów, wyłączenie ze wspólnoty, zadośćuczynienie (Bogu przede wszystkim, czyli pokuta w węższym znaczeniu) oraz rekoncyliacja, czyli przywrócenie grzesznika na łono chrześcijańskiej społeczności. Będę się starać podkreślić znaczenie autorytetu w motywowaniu poczynań biskupów oraz ukazać, jak Halitgar oraz zleceniodawca jego pracy Ebbo, arcybiskup Reims, czy inni reprezentanci tego środowiska, mogli sobie wyobrażać funkcjonowanie pokuty w kierowanej przez nich społeczności chrześcijan. Postawiona zostanie kwestia, czy penitencjał Halitgara mógł być pomyślany przez inicjatora oraz redaktora jako obdarzona sankcją kościelnej władzy, powszechnie w ramach państwa karolińskiego obowiązująca pomoc dla duszpasterzy i ewentualnie co stało na przeszkodzie realizacji tak daleko idących zamysłów. Zajmę wreszcie stanowisko w dyskusji nad nie tym planowanym, lecz ziszczonym w Kościele IX w. zastosowaniem tekstu Halitgara. Czy służył duchownym na poziomie parafii, czy raczej jednak biskupom, sądom biskupim i szkołom kształcącym kościelną elitę? Jest to rzeczywista alternatywa i w kwestii tej, podobnie jak w powiązanej z nią sprawie upowszechnienia spowiedzi pośród laikatu, pojawiały się w ostatnich latach ważkie głosy ${ }^{4}$.

${ }^{4}$ Argumentacja przeciwko powszechności spowiedzi - por. m.in. A. Murray, Confession before 1215, „Transactions of the Royal Historical Society” 3, 1993, s. 51-81; przedruk w: idem, Conscience \& Authority in the Medieval Church, Oxford 2015, s. 17-48 - tu przywoływane według owego nowszego wydania; głos za powszechnością powtarzalnej pokuty - D. Bachrach, Confession in the Regnum Francorum (742-900). The Sources Revisited, "Journal of Ecclesiastical History" 54, 2003, s. 3-22; także H. von Soden, Confessio zwischen Beichte und Geständnis. Eine dogmengeschichtliche Betrachtung über die Entwicklung des Schuldbekenntnisses vom römischen Recht bis zum IV. Lateranum, (Inaugural-Dissertation zur Erlangung des Grades eines Doktors der Rechte durch die Rechts- und Staatswissenschaftliche Fakultät der Rheinischen Friedrich-Wilhelms-Universität Bonn) 2010, http://hss.ulb.uni-bonn.de/2010/2285/2285.pdf; wyd: książkowe: Confessio zwischen Beichte und Geständnis. Eine dogmengeschichtliche Betrachtung über die Entwicklung des Schuldbekenntnisses vom römischen Recht bis 1215 n.Chr., Bonn 2011. 
Dla ułatwienia lektury ten mój stosunkowo obszerny tekst został podzielony na podrozdziały. $\mathrm{W}$ ramach pierwszego przypomniana została geneza i funkcjonowanie penitencjałów. W drugim mowa o stosunku karolińskiego episkopatu do zagadnień pokuty i do wspomnianych tekstów. W trzecim uwaga została skoncentrowana na okolicznościach powstania traktatu Halitgara i na problemie autorytetu. Czwarty zawiera omówienie kluczowych problemów podjętych przez Halitgara. Piąty ujmuje uwagi i wnioski dotyczące celów, które przyświecały inicjatorom, realizacji tychże celów, oraz zastosowania, jakie - niezależnie od autorskich intencji - znajdować mógł w kolejnych pokoleniach tekst biskupa Cambrai.

\section{Penitencjały - początki, upowszechnienie, kontrowersje wokół ich stosowania}

Warto skrótowo przybliżyć ów szczególny rodzaj tekstów, który znajdzie się w centrum rozważań ${ }^{5}$. Penitencjały wywodzą się z Irlandii. Powstały w środowisku monastycznym, łatwo wszakże dostosowano je do potrzeb działań duszpasterskich wobec wiernych wszystkich kategorii. Ich charakterystyczną cechę stanowiło połączenie poszczególnych, dosyć precyzyjnie opisanych grzechów z wymiarem pokuty - okresem postu, zamienianego czasem na innego rodzaju praktyki, z materialnymi ofiarami włącznie. Przy wstępnej lekturze nieodparcie przypominają kodeksy praw (dwuczłonowa konstrukcja: wina i sankcja). Sprawiają nadto wrażenie swoistych taryf. I mówi się w związku z nimi o pokucie taryfikowanej. Była to pokuta prywatna, inna niż publiczna, charakteryzująca wcześniejszy okres historii Kościoła. Jej sukces oznaczał w praktyce odejście od oceniania każdego grzesznika i grzechu przez biskupa, uniwersalizację pokuty - czyli objęcie nią wszystkich chrześcijan niezależnie od stanu,

${ }^{5}$ Oprócz przywoływanej dalej literatury poświęconej konkretnym penitencjałom lub tematom w nich poruszanym warto tu wskazać syntetyczne opracowanie: C. Vogel, Les Libri Paenitentiales, Turnhout 1978, jak też: J.T. McNeill, H.M. Gamer, Medieval handbooks of penance. A translation of the principal "libri poenitentiales" and selections from related documents, New York 1938; 2. wyd. 1990, gdzie oprócz angielskich przekładów najważniejszych tekstów, na s. 3-50 mieści się obszerne, wielowątkowe, wciąż cytowane w literaturze wprowadzenie, syntetycznie omawiające historię pokuty i wczesnych penitencjałów, w tym ich związki z systemami prawnymi Celtów i Germanów. Wprowadzenie do aktualnych kierunków badań - tu w kontekście konkretnego projektu badawczego - R. Meens, Introduction. Penitential Questions. Sin, Satisfaction and Reconciliation in the Tenth and Eleventh Centuries, „Early Medieval Europe” 14, 2006, 1, s. 1-6. 
jak również jej formalizację $e^{6}$ Znamionować miał zarazem, zdaniem niektórych historyków, odejście od antycznej jeszcze tradycji zaawansowanej refleksji teologicznej i dostrzegania poza grzechem grzesznika z jego intencjami, okolicznościami popełnienia czynu itp. na rzecz religijności uproszczonej, skoncentrowanej na samym czynie, na szkodach przezeń wywołanych i ich „liczbowym" rekompensowaniu”. Ich treść miała stanowić efekt zderzenia chrześcijaństwa z archaiczną iryjską kulturą prawną, w której czyn liczy się dużo bardziej niż intencja, co najbardziej się uwidoczniło $\mathrm{w}$ przepisach dotyczących wszelkiego typu naruszeń czystości zewnętrznej - rytualnej ${ }^{8}$.

Penitencjały od dawna są przedmiotem zainteresowania mediewistów - pod różnym kątem. Służą pomocą w badaniach nad historią pokuty - w tym liturgii pokutnej w Kościele. Są źródłem w odniesieniu do teologii i liturgiki ${ }^{9}$. Ze szczyptą złośliwości rzecz ujmując, także ze

${ }^{6}$ Por. A. Angenendt, T. Braucks, R. Busch, H. Lutterbach, Counting Piety in the Early and High Middle Ages, w: Ordering Medieval Society. Perspectives on Intellectual and Practical Modes of Shaping Social Relations, wyd. B. Jussen, Philadelphia 2001, s. 15-54. Jest to skrócona postać artykułu tychże autorów oraz Thomasa Lentesa, Gezählte Frommigkeit, „Frühmittelalterliche Studien” 29, 1995, s. 1-71; dalej cytowane przeze mnie według angielskiej wersji, tu s. 23. Rezygnując z przytaczania rozległej literatury dotyczącej historii pokuty w Kościele pierwszego tysiąclecia - do niektórych pozycji i tak wypadnie się odwołać - można tu jako rodzaj wprowadzenia zalecić artykuł M. de Jong, Transformations of Penance, w: Rituals of Power - From Late Antiquity to the Early Middle Ages, red. F. Theuws, J.L. Nelson, Leiden-Boston-Köln 2000, s. 185-224.

7 Taki punkt widzenia, zaznaczyć trzeba: dyskusyjny, najmocniej wyartykułował w ostatnich latach Hubertus Lutterbach, Die mittelalterliche Bußbücher - Trägermedien von Einfachreligiosität?, „Zeitschrift für Kirchengeschichte” 115, 2003, 2, s. 227-244. Szczególne wątpliwości budzi tutaj ostre przeciwstawienie bardziej wyrafinowanego jakoby w swojej praktyce Kościoła późnej starożytności uproszczonej, cywilizacyjnie pierwotniejszej religijności wczesnego średniowiecza. Por. idem, Die Bußordines in den iro-fränkischen Paenitentialien. Schlüssel zur Theologie und Verwendung der mittelalterlichen Bußbücher, „Frühmittelalterliche Studien” 30, 1996, s. 150-172, w szczególności s. 150.

${ }^{8}$ H. Lutterbach, Intentions- oder Tathaftung? Zum Büßverständnis in den frühmittelalterlichen Bußbüchern, „Frühmittelalterliche Studien” 29, 1995, s. 141, 131-133. Opinia polemiczna - intencja grzesznika była uwzględniana w penitencjałach - por. R. Kottje, Intentions- oder Tathaftung? Zum Verständnis der frühmittelalterlichen Bußbücher, „Zeitschrift der Savigny-Stiftung für Rechtsgeschichte”, Kanonistische Abteilung 91, 2005, s. 738-741. Do wątku czystości w penitencjałach, której naruszenie znajdowało się pod sankcją por. m.in. R. Meens, Politics, Mirrors of Princes and the Bible. Sins, Kings and the Well-Being of the Realm, „Early Medieval Europe” 7, 1998, 3, s. 346 nn.

${ }^{9}$ Por. teksty polskich duchownych i teologów jak: M. Kieling, Zasady ogólne dotyczace praktyk pokutnych na podstawie „Libri poenitentiales”, „Vox Patrum” 67, 2017, s. 225-240; T. Nawracała, Kwestia wiary w jednego Boga w perspektywie ksiag pokutnych i przygotowania do spowiedzi furtkowej, w: Współczesne oblicza wiary, red. idem, Poznań 2016 s. 81-94. W polskiej literaturze istnieje również omówienie z perspektywy 
względu na bardzo przystępną łacinę ${ }^{10}$ stały się wdzięcznym materiałem dla prac o historii seksualności, podejścia do różnych aspektów płciowości, prokreacji, magii itd. Wśród tych prac są zresztą i dzieła fundamentalnie ważne, oparte na rozległej kwerendzie ${ }^{11}$.

Wraz z iryjskimi mnichami penitencjały pojawiły się w Brytanii i na kontynencie - w Galii prawdopodobnie od początku VIII stulecia (najstarsze zachowane rękopisy zawierające iryjskie księgi pokutne pochodzą z końca tego wieku, przede wszystkim z terenów północnej Francji). Doceniono „genialność” wynalazku - penitencjały owej epoki mieściły się w małych, wygodnych w użytkowaniu książeczkach ${ }^{12}$. Kopiowano i użytkowano te iryjskie. Wkrótce zaczęto tworzyć nowe - przy czym wpisany nieomal w ich istotę kompilatorski charakter dzieł każe się mocno zawahać nad użyciem epitetu „oryginalne” w tym rozumieniu,

historyka: P. Matwiejczuk, Pokuta kościelna w świetle penitencjałów z terenów Francji i Italii z VIII i IX wieku. Próba rekonstrukcji rzeczywistości historycznej, w: Karolińscy pokutnicy i polskie średniowieczne czarownice. Konfrontacja doktryny chrześcijańskiej z życiem społeczeństwa średniowiecznego, red. M. Koczerska, Warszawa 2007, s. 9-89- w przedstawieniu pokuty wczesnośredniowiecznej silnie zależne od dosyć uproszczonych ujęć kościelnych historyków liturgii, a w realizacji wyrażonej w podtytule formuły „rekonstrukcja rzeczywistości historycznej" - metodologicznie dyskusyjne.

10 Skądinąd maksymalne uproszczenie stylistyczne, językowe i strukturalne w penitencjałach zdaje się wskazywać na jedynie rudymentarnie wyedukowanych kapłanów jako na pierwszych ich odbiorców - por. F. Kerff, Libri paenitentiales und kirchliche Strafgerichtsbarkeit bis zum Decretum Gratiani. Ein Diskussionsvorschlag, „Zeitschrift der Savigny-Stiftung für Rechtsgeschichte", Kanonistische Abteilung 75, 1989, s. 27 i przyp. 12 tamże.

${ }^{11} \mathrm{Na}$ taką ocenę w oczach specjalistów zasłużyła sobie np. monografia Pierre'a J. Payera, Sex and the Penitentials. The Development of a Sexual Code, 550-1150, Toronto 1984. W polskiej literaturze penitencjały w kontekście odzwierciedlenia w nich norm dotyczących życia seksualnego przywołał Krzysztof Skwierczyński, Mury Sodomy. Piotra Damianiego „Księga Gomory” i walka z sodomią wśród kleru, Kraków 2011, s. 55-60.

${ }^{12} \mathrm{O}$ kierunkach i ramowej chronologii szerzenia się gatunku por. R. Meens, Remedies for Sins, w: The Cambridge History of Christianity, t. 3: Early Medieval Christianity, c.600c.1100, red. T.F.X. Noble, J.M.H. Smith, Cambridge 2008, s. 407. Zdaniem uczonego w przypadku Brytanii można zresztą mówić o „reintrodukcji” penitencjałów - wtórnym ich przyjęciu w IX i X w. z kontynentu. Hubert Mordek, Kanonistische Aktivität in Gallien in der ersten Hälfte des 8. Jahrhunderts: Eine Skizze, „Francia” 2, 1974, s. 20, stwierdza obecność w Galii od początku VIII w. wyspiarskich penitencjałów, pseudo-Teodora i Excarpsus Cummeani; stały się one według tego badacza źródłem czy inspiracją galijskiego prawa kanonicznego. O walorze „portability” (z tego powodu okazały się też trudne do kontrolowania i do zwalczenia), jak też dużym znaczeniu penitencjałów w świecie frankijskim: A.J. Frantzen, The Significance of the Frankish Penitentials, „Journal of Ecclesiastical History" 30, 1979, 4, s. 412, 409-410; także: R. Kottje, Überlieferung und Rezeption der irischen Bußbücher auf dem Kontinent, w: Die Iren und Europa im früheren Mittelalter, red. H. Löwe, Stuttgart 1982, s. 511-523. 
do jakiego przywykliśmy w naszej epoce ${ }^{13}$. W okresie od VI do IX w. powstało we wszystkich tych trzech obszarach (w Irlandii, Brytanii i na kontynencie) wiele tekstów reprezentujących gatunek. Do czasów karolińskich większość z nich była anonimowa lub apokryficzna - to znaczy towarzyszyła im mająca wątpliwe podstawy atrybucja do ważnych postaci insularnego chrześcijaństwa tych wieków (Kolumban, Teodor z Tarsu/Canterbury, Beda Czcigodny). Ich mnogość wskazywałaby na istniejące realne zapotrzebowanie, najpewniej ze strony duszpasterzy na co dzień działających wśród wiernych.

Nie wiadomo, kiedy penitencjały mogły zaczać być stosowane szerzej w kontynentalnej praktyce. Zajmujący się bardzo wszechstronnie tym gatunkiem Rob Meens sugeruje, że to od drugiej połowy VIII w. kapłani (w domyśle: w obszarze frankijskim) przy nakładaniu pokut coraz częściej posiłkowali się pisemnymi pomocami ${ }^{14}$. Trudno tu jednak o dowód. Wskaźnikiem popularności gatunku jest też liczba zachowanych rękopisów z kopiami penitencjałów - jest ich około 400 dla obszaru dzisiejszej Francji, Włoch, Hiszpanii i Angliii ${ }^{15}$. Nic konkretnego nie wiadomo jednak o tym, jak na co dzień były one użytkowane. „Zdroworozsądkowo” brzmi sugestia Pierre'a J. Payera, iż spowiednik nie tyle miał penitencjał pod ręką w trakcie wysłuchiwania spowiedzi, co traktował go jako swoisty przewodnik informujący o rodzajach grzechów, o okolicznościach obciążających i łagodzących, i o sugerowanych pokutach ${ }^{16}$.

13 Por. „die Masse der frühmittelalterlichen Bußbücher ist alles andere als originell: Nicht die Erfassung immer neuer, gewissermaßen tagesaktueller Sünden und Probleme war ihr Fall, sondern die Sammlung und Redaktion des immer gleichen Materials", L. Körntgen, Bußbuch und Bußpraxis in der zweiten Hälfte des 9. Jahrhunderts, w: Recht und Gericht in Kirche und Welt um 900, wyd. W. Hartmann, A. Grabowsky, München 2007, s. 197. Por. A.J. Frantzen, The Tradition of Penitentials in Anglo-Saxon England, „Anglo-Saxon England" 11, 1982, s. 36, gdzie dokonano klasyfikacji penitencjałów kontynentalnych z podziałem na trzy duże grupy.

${ }^{14}$ R. Meens, Die Bußbücher und das Recht im 9. und 10. Jahrhundert. Kontinuität und Wandel, w: Recht und Gericht, s. 217. Tamże, s. 217-219 godne uwagi ze względu na swoją klarowność przedstawienie powiązań między penitencjałami spisywanymi między VI a VIII stuleciem. W każdym razie nie sposób uznać penitencjałów na gruncie frankijskim za efemeryczny obcy wtręt, który ostatecznie został odrzucony - jak pisała Rosamond Pierce, The „Frankish” penitentials, w: The Materials, Sources and Methods of Ecclesiastical History, wyd. D. Baker, Oxford 1975, s. 34.

${ }^{15}$ R. Kottje, Intentions- oder Tathaftung?, s. 739, przyp. 4; H. Lutterbach, Die mittelalterliche Bußbücher, s. 227-228; Rob Meens, Frequency and Nature of Early Medieval Penance, w: Handling Sin. Confession in the Middle Ages, red. P. Biller, A.J. Minnis, Woodbridge 1998, s. 39, pisze z kolei o około 300 rękopisach z okresu 800-1000 zawierających tylko penitencjały.

16 P.J. Payer, Sex and the Penitentials, s. 8. 
Owa mnogość penitencjałów stworzyła nie lada problem z perspektywy ówczesnej elity biskupiej. W historii gatunku wyróżnić można skądinąd dwa okresy wzmożonego krytycyzmu wobec penitencjałów właśnie z tego kierunku: w epoce karolińskiej oraz gregoriańskiej - kiedy zresztą już nie powstawały nowe ${ }^{17}$. Tu interesuje nas tylko kontestacja karolińska. Od razu warto uprzedzić, że był to problem inny, aniżeli ten, który może mieć współczesny czytelnik penitencjałów - dla niego właściwie chyba niezależnie od światopoglądu potraktowanie pokuty za etyczne przekroczenie (grzech) w kategoriach taryf będzie egzotyczne ${ }^{18}$. Do karolińskich biskupów nie przemówiłby też zarzut, że w penitencjałach połączono zaawansowaną kulturowo formę przekazu - pismo, z prostymi formami wyrażania czy praktykowania religijności ${ }^{19}$.

Po pierwsze zatem: żaden z tekstów nie zdobył sobie autorytetu pozwalającego na powszechne uznanie jego obowiązującego charakteru. Duszpasterze mogli mieć problem z wyborem penitencjału odpowiadającego ich potrzebom - o ile oczywiście mieli dostęp do większej liczby tekstów, to wówczas bowiem groziła im swoista klęska urodzaju (czy też „die Qual der Wahl”, jak to określił, co prawda odnosząc to akurat do drugiej połowy IX w., Ludger Körntgen ${ }^{20}$ ). Część starszych penitencjałów była ukierunkowana na grzechy społeczności monastycznej (np. wywierający wpływ na liczne młodsze teksty Ambrosianum) lub tylko kapłańskiej ${ }^{21}$. W nieunikniony sposób penitencjały różniły się między

17 O krytycyzmie wobec penitencjałów w dwóch fazach, karolińskiej i gregoriańskiej (w tym drugim okresie z problemem zmierzyli się tacy autorzy, jak Piotr Damiani czy kardynał Atto od św. Marka), w związku z koncepcją autorytetu i koncentrując się na Italii XI-XII w., pisał Adrian Gaastra, Penitentials and Canonical Authority, w: Texts and Identities in the Early Middle Ages, wyd. R. Corradini et al., Vienna 2006, s. 191-204.

18 Por. opinia znawcy penitencjałów na temat współczesnego ich odbioru: „It is true that their piety appals more often than it inspires, and their anatomy of sin and its wages is discouraging and depressing to behold", A.J. Frantzen, The Significance, s. 421. Tamże na s. 410 syntetycznie o powodach krytyki penitencjałów w państwie Franków.

19 Jak pisał H. Lutterbach, Die mittelalterliche Bußbücher, s. 227: „Die Zusammenwirken von hochkultürlicher Memotechnik und einfachreligiösen Ausdrucksformen ist charakteristisch für die allermeisten Bußbücher...".

${ }^{20}$ L. Körntgen, Bußbuch und Bußpraxis, s. 200. Por. też uwagi Rachel Stone, Morality and Masculinity in the Carolingian Empire, Cambridge 2012, s. 34: „[Penitencjały były] continually reused and reworked but... no text can be seen as authorative".

${ }^{21}$ Taki zorientowany na kapłanów penitencjał zachował się na przykład w Mszale z Bobbio, którego rękopis datowany jest na koniec VII w., a treść dokumentuje troskę o reformę życia kleru w Burgundii w końcu VI w. - w epoce merowińskiego króla Guntramma; por. R. Meens, Reforming the Clergy. A Context for the Use of the Bobbio Penitential, w: The Bobbio Missal. Liturgy and Religious Culture in Merovingian Gaul, wyd. Y. Hen, R. Meens, Cambridge 2009, s. 154-167. 
sobą. Łatwo więc wyobrazić sobie sytuację, w której dwóch pracujących po sąsiedzku duszpasterzy w oparciu o różne penitencjały nakłada za te same powszechne grzechy inne pokuty. Powstać mogło wrażenie chaosu w tak wrażliwym obszarze norm. Więcej nawet: w tym samym penitencjale w różnych jego częściach za identyczny lub trudny do rozróżnienia grzech przewidywano, bez dodatkowych wyjaśnień, rozbieżne wymiary pokuty. Wynikać to mogło z niedbalstwa w kompilowaniu, mogło być też zawoalowanym wskazaniem spowiednikom, że od ich discretio zależy w związku z konkretnymi okolicznościami - wybór surowszej lub łagodniejszej pokuty ${ }^{22}$. Przyznawanie kapłanom takiej władzy, milcząco zakładane lub jawnie wspominane w penitencjałach, też mogło budzić wśród biskupów kontrowersje ${ }^{23}$.

Jeszcze poważniejszym problemem była równie nieunikniona sprzeczność między zapisami z konkretnych ksiąg pokutnych a dotyczącymi tych samych problemów postanowieniami synodów. Przez stulecia wznoszona była przecież wielka budowla prawa kanonicznego. Na długo przed scentralizowaniem kościelnego prawodawstwa kanony niektórych synodów należących do (z naszej perspektywy) późnej starożytności i wczesnego średniowiecza zdobyły sobie uznanie jako rozstrzygnięcia wzorcowe i obowiązujące. Dotyczyły one także postępowania z grzesznikami. A inaczej niż penitencjały, miały niekwestionowany autorytet. Ich ciągłemu przypominaniu służyły kolekcje czy też zestawienia redagowane w interesującej nas, karolińskiej erze. Wówczas bowiem świadomie włożono wysiłek w ożywienie tego, co nazywano canonum decreta et aecclesiae iura ${ }^{24}$. Tymczasem żaden penitencjał nie uzyskał rekomendacji jakiegokolwiek papieża, soboru czy synodu, co utrzymywało je w sytuacji

${ }^{22}$ Por. H. Lutterbach, Die mittelalterliche Bußbücher, s. 231, przyp. 23 z przykładem $\mathrm{z}$ iryjskiego Excarpsus Cummeani, gdzie za obcowanie płciowe ze zwierzętami w jednym miejscu przewiduje się post trwajacy 15 lat, w innym - rok lub dwa, z wyjaśnieniem, że chodzi o świeckich. O odwoływaniu się do discretio por. A. Gaastra, Penitentials, s. 196; R. Meens, Pollution in the Early Middle Ages. The Case of the Food Regulations in Penitentials, „Early Medieval Europe” 4, 1995, 1, s. 4.

${ }^{23}$ Por. R. Pierce, op. cit., s. 33-34.

${ }^{24}$ H. Mordek, Kirchenrechtliche Autoritäten im Frühmittelalter, w: Recht und Schrift im Mittelalter, red. P. Classen, Sigmaringen 1977, s. 242. Ten sam autor zwraca uwagę, że za pierwszych Karolingów na dużą skalę wykorzystywano materiał synodów późnej starożytności, ale programowo wręcz ignorowano bliższe czasowo synody merowińskie; zaczęto się do nich odwoływać dopiero w latach czterdziestych IX w. - ibidem, s. 251. Por. też: A. Fiori, Roman Law Sources and Canonical Collections in the Early Middle Ages, „Bulletin of Medieval Canon Law", new series 34, 2017, s. 1-2: uwagi na temat niejednorodności prawa kanonicznego, rozwijającego się w okresie przedgregoriańskim w kilku nurtach lokalnych tradycji w dialektycznej relacji do Kościoła rzymskiego. 
zbiorów o niejako prywatnym charakterze, komponowanych i rekomendowanych następnie raczej nieoficjalnie (skądinąd Dekret Gracjana w pierwszym okresie po napisaniu nie był niczym więcej) $)^{25}$. Redaktorzy byli świadomi konsekwencji tego faktu: penitencjały więc rekomendowały wymiary pokut, nie narzucały ich w formie dyktatu ${ }^{26}$.

Autorzy czy kompilatorzy interesujących nas tutaj jako gatunek ksiąg pokutnych owszem, korzystali ze zbiorów kanonów synodalnych obficie ale każdorazowo była to autorska (zazwyczaj anonimowa, powtórzmy) selekcja obszernego materiału ${ }^{27}$. Nie podawano źródeł lub podawano je wyrywkowo. W starszych iryjskich penitencjałach przywoływano enigmatycznie „ojców” i „mądrych ludzi”. Przeciętny użytkownik penitencjałów - kapłan administrujący pokutami - przy miernej znajomości prawa kanonicznego często nawet nie był w stanie odróżnić w swoim podręczniku materiału synodalnego od własnego wkładu twórcy księgi ${ }^{28}$. Zignorowanie zapisów konkretnych kanonów musiało się przeto zdarzać. Dla biskupów epoki karolińskiej owa sytuacja miała wszakże chyba posmak ryzyka: jak bowiem odnieść się do interpretacji dokonanej przez nieznanego iryjskiego mnicha w sprzeczności z szacownymi kanonami?

Jest też jasne, że niektóre znajdujące się w obiegu penitencjały iryjskiego pochodzenia - łatwo, przynajmniej w założeniu, dostępne dla duchownych, bo tworzone $w$ łacinie, i na kontynencie już kopiowane pismem, z którym kontynentalny właśnie czytelnik był bardziej oswojony, aniżeli z wyspiarskim (abstrahując od tego, na ile w naszym odbiorze akurat pismo iryjskich skryptoriów może być przystępniejsze ${ }^{29}$

25 T.P. Oakley, The Penitentials as Sources for Medieval History, „Speculum” 15, 1940, 2, s. 217; A. Angenendt, T. Braucks, R. Busch, H. Lutterbach, op. cit., s. 31.

${ }^{26}$ Por. E.W. Abraham, Anticipating Sin in Medieval Society. Childhood, Sexuality and Violence in Early Penitentials, Amsterdam 2017, s. 9.

27 Por. R. Meens, Die Bußbücher und das Recht, s. 219 o wplataniu synodalnych ustaleń do penitencjałów o kolumbańskim rdzeniu i łączeniu penitencjału Excarpsus Cummeani z kanonami ze zbioru Collectio Vetus Gallica. Prywatny, autorski (jak również retoryczny) charakter penitencjałów podkreślał K. Skwierczyński, op. cit., s. 56.

${ }^{28}$ R. Meens, Die Bußbücher und das Recht, s. 219. W penitencjale z przełomu VIII i IX w. o iryjskim prawdopodobnie pochodzeniu, tzw. Bigotianum, odwołanie się do „ojców” służy wręcz jako alibi dla własnej śmiałości - por. „si in hoc paenitentiale temperamento plus minusuae ante oculis creatoris videatur, non nostrae audaciae culpa est; maiorum enim decreta, non nostra exposuimus", Paenitentiale quod dicitur Bigotianum, w: The Irish penitentials, wyd. L. Bieler, D.A. Binchy, Dublin 1963, c. 4. s. 198.

${ }^{29}$ Wczesne kontynentalne kopie penitencjałów sporządzano jeszcze insularnym pismem - lub pismem z cechami insularnymi - A.J. Frantzen, The Significance, s. 413. $\mathrm{Na}$ ten temat też R. Kottje, Überlieferung und Rezeption, s. 517-518. Rosamond Pierce, op. cit., s. 35, sugerowała natomiast, że wszystkie rękopisy penitencjałów tej wczesnej epoki są spisane owym wyspiarskim pismem. 
nie przystawały do warunków państwa Franków. W drugiej połowie VIII i początkach IX w. mnożyły się kompilacje budowane głównie w oparciu o penitencjały znane pod imionami Cummeana, Teodora i Kolumbana, kompilacje anonimowe, obszerne i wewnętrznie sprzeczne, bezplanowe i w efekcie chyba bezużyteczne w codziennej praktyce - nienadające się na podręcznik spowiednika. Dodatkowo pokuty w nich zawarte uznawano czasem za zbyt surowe. To zapewne też pobudzało członków kościelnej elity do refleksji ${ }^{30}$.

Osobna, istotna (w nauce skądinąd wywołująca wciąż dyskusje wobec niejednoznaczności zagadnienia) kwestia to obiekcje wobec prywatnej pokuty jako takiej. Przykładowo synod z Toledo w 589 r. skrytykował penitencjały, wskazując jednoznacznie, że to uświęcona tradycją pokuta publiczna winna być preferowana ${ }^{31}$. Owa publiczna pokuta była rytem bardziej solennym i w życiu chrześcijanina nie tylko nie zdarzała się regularnie, ale wręcz bywała zalecana do odbywania tylko raz w życiu. Zdaniem teologów i biskupów epoki pokuta prywatna zbyt szerokie uprawnienia - spośród tych ongiś zarezerwowanych dla biskupów przyznawała jednak szeregowym duchownym ${ }^{32}$.

\section{Karoliński episkopat wobec problemu pokuty}

Ten stan rzeczy: obecność penitencjałów, ich wykorzystywanie przez duchownych, narastająca wśród przynajmniej części biskupów rezerwa wobec tych tekstów - określa kontekst reformy w obszarze pokuty, do której przymierzono się w czasach Karola Wielkiego. W procesie, którego nie ma możliwości tutaj bardziej szczegółowo przedstawiać, Karol, krąg jego duchownych doradców i kreowany przezeń episkopat przystąpili do zmian w różnych dziedzinach życia kościelnego. Reforma liturgii to tylko jeden aspekt. Zatroszczyli się też m.in. o formowanie duchownych na najbardziej podstawowym, parafialnym poziomie. Doceniono przy tym, że do najważniejszych ich zadań należy nakładanie i egzekwowanie pokut.

${ }^{30}$ H. Mordek, Kanonistische Aktivität, s. 21, zauważa, że mimo sprzeczności z kanonami oraz surowości regulacji penitencjały nie mogły być już jednak wyeliminowane (w warunkach Galii VIII w.) z kościelnej praktyki. Jeszcze inny aspekt to owo iryjskie pochodzenie penitencjałów - Rosamond Pierce, op. cit., s. 32-33, dopatruje się w potępieniu penitencjałów przez biskupów z początku IX w. śladu ksenofobicznych tendencji wśród Franków.

31 A.J. Frantzen, The Literature of Penance in Anglo-Saxon England, New Brunswick N.J. 1983, s. 97.

${ }^{32}$ Ibidem, s. 98. 
Odpowiednie intelektualne wyposażenie takich duchownych stało się jedną z najbardziej palących kwestii. Karol w swoim prawodawstwie (na przykład w Admonitio generalis z 789 r.) zalecał, ażeby czytać w kościołach księgi kanoniczne (tj. ortodoksyjne) i otwarcie przestrzegał przed pismami fałszywymi i szkodliwymi, sprzecznymi z wiarą katolicką ${ }^{33}$. Choć kontekstem dla słów z Admonitio były tzw. listy z nieba, na błąd i fałszerstwo narażony był w przekonaniu wąskiej elity nowego imperium także obszar pokuty. Dlatego, choć nie tak znów szybko, synody i poszczególni biskupi zajęli się problemem materiałów służących pomocą i w tej dziedzinie.

Za swego rodzaj wstęp do sprawy uznać można precedensowe wezwanie wystosowane przez Karola Wielkiego jesienią $807 \mathrm{r}$. Znane jest ono $z$ listu do biskupa Gerbalda $z$ Leodium (Liège) ${ }^{34}$. Cesarz zobowiązał hierarchę - jako jednego z wielu adresatów w imperium: innych biskupów, może i hrabiów ${ }^{35}$ - do zorganizowania w diecezji trzech trzydniowych okresów postu, którym towarzyszyć miały publiczne modlitwy, procesje i rozdzielanie jałmużn. Wskazówki dotyczące ich przeprowadzenia, łącznie z tymi chronologicznymi, są nader drobiazgowe. Mowa jest na przykład o tym, kto może zostać wyłączony z poszczenia; podane zostały daty. Jako uzasadnienie list Karola wskazywał quasdam necessitates. Wśród nich wymienione zostały nieurodzaj i groźba głodu, zaraza, najazdy pogan na pograniczne marchie. Zalecany ryt nosił znamiona pokuty (posty). Służyć miał przebłaganiu Boga. W oczywisty sposób czynił wszystkich wiernych odpowiedzialnymi za odwrócenie niekorzystnych zrządzeń Opatrzności. Dlatego właśnie jego treść miała być obwieszczana wszędzie w kościołach i klasztorach, w razie potrzeby przez tłumaczy. Władca oczekiwał powszechnego udziału $\mathrm{w}$ postach. List zawierał zresztą rozszerzone wyjaśnienie tego punktu widzenia.

Właśnie szczegółowość zaleceń zbliża nas do tematu pokuty. Cesarz, czy też ludzie z jego otoczenia, którzy wpadli na ów pomysł, rozumowali w duchu zbliżonym do znanego z penitencjałów. Oto najwyraźniej ich zdaniem potężnym - choć nie wyznanym - grzechom społeczności można przyporządkować swego rodzaju taryfę.

Władca i biskupi mieli zatem współdziałać w aranżowaniu działań pokutnych. Tak realizowało się zaangażowanie Kościoła w budowanie karolińskiego ładu społecznego i politycznego. Ten czas cechuje według

${ }^{33}$ Por. J. Szaciłło, Reforma liturgiczna VIII wieku w świetle kapitularzy Karola Wielkiego (miejsca i przedmioty liturgiczne), w: Sacrum. Obraz i funkcja w społeczeństwie średniowiecznym, red. A. Pieniądz-Skrzypczak, J. Pysiak, Warszawa 2005, s. 216.

${ }^{34}$ Karoli ad Ghaerbaldum episcopum epistola, wyd. A. Boretius, w: MGH, Capitularia regum Francorum, cz. 1, Hannoverae 1883 (dalej: Capitularia 1), s. 244-245.

${ }^{35}$ R. Meens, Politics, s. 345. 
niektórych autorów wzrost liczby kościelnych sądów ${ }^{36}$. Źródła odzwierciedlają rosnące poczucie odpowiedzialności karolińskich biskupów za wymierzanie sprawiedliwości. Pokazują ich zaangażowanie w proces kontroli społecznej ${ }^{37}$. Z perspektywy kościelnej elity istotne stawało się wdrażanie duchownych do kooperacji z przedstawicielami władzy królewskiej przy zachowywaniu porządku, rozwiązywaniu konfliktów.

Poprzez penitencjały - w pośrednim, ale zrozumiałym mechanizmie - możliwe było oddziałanie na kapłanów w tym zakresie. Nakładane i egzekwowanie pokut miało wymiar społeczny. Zazębiało się ze stosowaniem prawa. Nie wiadomo, jak ostra z perspektywy ludzi Kościoła była różnica między pokutą za grzechy a karą za przestępstwa (skoro terminy grzech i przestępstwo obejmowały często te same czyny) i pomiędzy duszpasterstwem a praktykowaniem sprawiedliwości ${ }^{38}$. Legislacja Karola Wielkiego desygnowała wszakże wyraźnie biskupów do czynnej roli w sprawowaniu cesarskiej sprawiedliwości - i to w związku z ,wewnątrzkościelnym" rozwojem refleksji nad grzechami głównymi ${ }^{39}$. Rob Meens zwracał dodatkowo uwagę na współudział pokuty - zarówno w znaczeniu tego, co grzesznik miał wykonać, aby powrócić na pełnych prawach do społeczności wiernych, jak też w znaczeniu całej otoczki rytualnej, która przecież także w przypadku tak zwanej pokuty prywatnej miała publiczny, tzn. jawny charakter - w rozwiązywaniu jednostkowych konfliktów. W takim właśnie kontekście penitencjały mogły być stosowane. Ich zapisy dotyczyły tak ciężkich przekroczeń jak zabójstwo, zranienie, kradzież czy zdrada małżeńska, które, nawet jeśli popełniane we względnym ukryciu, w małych społecznościach dość łatwo mogły zostać przypisane konkretnemu sprawcy i otwierać tym samym konflikt, którego opanowanie stawało się zadaniem nie tylko „świeckiej” sprawiedliwości ${ }^{40}$.

${ }^{36}$ A. Firey, op. cit., s. 191.

37 A. Murray, op. cit., s. 25.

38 R. Meens, Die Bußbücher und das Recht, s. 220.

${ }^{39}$ Kapitularz akwizgrański datowany na 802/803 r. zawierał już w pierwszym swoim punkcie następujące wezwanie: „Ut episcopi circumeant parrochias sibi et ibi inquirendi studium habeant de incestu, de patricidiis, fratricidiis, adulteris, cenodoxiis et alia mala quae contraria sunt Deo, quae in sacris scripturis leguntur quae Christiani devitare debent", MGH Capitularia 1, s. 170, c. 1. Abigail Firey, Blushing, s. 192, zwraca uwagę na to, że z końcowej części zdania wynikają w istocie nieograniczone możliwości rozszerzania przewinień, które biskupi mieli tropić, oraz na wchodzenie przez prawodawcę w sferę, w której dotąd najważniejsza była rola patrum familiae. Por. też: T.P. Oakley, The Cooperation of Medieval Penance and Secular Law, „Speculum” 7, 1932, 4, s. 515-524.

${ }^{40}$ R. Meens, Die Bußbücher und das Recht, s. 220, 228; idem, Sanctuary, Penance, and Dispute Settlement under Charlemagne. The Conflict between Alcuin and Theodulf of Orléans over a Sinful Cleric, „Speculum” 82, 2007, 2, s. 297. 
Deklarowana jako dobrowolna, pokuta odbywana pod osłoną sanktuarium cieszącego się prawem azylu osłaniała przestępcę - w tak poważnych właśnie sprawach jak zabójstwa oraz wykroczenia seksualne - przed zemstą rodu ofiar, a surowość tej pokuty przynajmniej do pewnego stopnia miała uczynić zadość poczuciu sprawiedliwości tak samych zainteresowanych, jak i całej lokalnej społeczności ${ }^{41}$.

$\mathrm{Na}$ to akurat zjawisko snop światła rzucił przeanalizowany w jednym z artykułów wspomnianego wyżej Roba Meensa spór z 801/802 r. wokół pewnego kleryka - grzesznika czy nawet przestępcy, który pod pozorem odbywania pokuty szukał schronienia w bazylice św. Marcina w Tours ${ }^{42}$. Zderzyły się wówczas stanowiska Teodulfa - biskupa miejscowej diecezji ze stolicą w Orleanie z jednej strony, i Alkuina, opata klasztoru św. Marcina, z drugiej. Tak się osobliwie złożyło, że byli to zarazem absolutnie pierwszoplanowi intelektualiści państwa Karola Wielkiego i ludzie rywalizujący ze sobą na różnych innych polach. W tym wypadku występowali trochę z tytułu wspomnianych funkcji. Alkuin bronił prawa kleryka do odbywania pokuty w bazylice. Teodulf domagał się, by opuścił azyl. Podejście pierwszego było bardziej „pastoralne”, drugiego - legalistyczne. Sam cesarz Karol przychylił się do stanowiska Teodulfa. Nie oznaczało to jednak w ostatecznym rozrachunku odmówienia sanktuariom prawa do przyjmowania pokutników. Ponieważ za Karolingów władcy oraz biskupi zyskali większą niż kiedykolwiek wcześniej kontrolę nad przestrzenią monastyczną, to przy gwarantowaniu klasztorom immunitetu możliwe się stało coraz częstsze wykorzystywanie ich jako miejsca pokuty grzeszników „ze świecznika”, w politycznym zaś sensie - miejsc „wewnętrznego wygnania”; wbrew pozorom nie dlatego, że widziano w nich więzienie, lecz raczej dlatego, gdyż miały status miejsc uświęconych ${ }^{43}$. W ten sposób ujawniała się komplementarność systemu pokuty i systemu świeckiej sprawiedliwości. Wyrażała się ona zresztą i w fakcie, że o ile dla tej ostatniej swego rodzaju gorsetem w coraz większym stopniu stawało się prawo w pisanej postaci,

${ }^{41}$ R. Meens, Sanctuary, s. 297. Ma to związek również z faktem, że dla części przynajmniej grzeszników przestrzenią pokuty zamiast kościoła pełnego wiernych, gdzie doznawali skutków segregacji - oddzielenia od wspólnoty - staje się klasztor; por. D. Iogna-Prat, Topographies of Penance in the Latin West (c.800-c.1200), w: A New History of Penance, s. 151-152. Kościół (budowla - miejsce kultu) natomiast musiał pozostać miejscem rekoncyliacji - ibidem, s. 163, 165.

${ }^{42}$ R. Meens, Sanctuary, s. 277-300.

${ }^{43}$ Szeroko na ten temat: M. de Jong, Monastic Prisoners or Opting out? Political Coercion and Honour in the Frankish Kingdoms, w: Topographies of Power in the Early Middle Ages, wyd. M. de Jong, F. Theuws, C. van Rhijn, Leiden-Boston-Cologne 2001, s. 291-328. 
o tyle spowiednikowi w większym stopniu wolno się było opierać na swojej discretio ${ }^{44}$.

W postanowieniach synodu z Chalon-sur-Saône z 813 r., o którym poniżej, znalazło się wezwanie ze strony biskupów, ażeby cesarz udzielał wsparcia w egzekwowaniu pokuty w przypadku publicznie popełnionych grzechów ${ }^{45}$. Jeszcze mocniej związek między wymierzaną przez kościelną władzę pokutą a działaniami władzy świeckiej wyrażony został poprzez kanon synodu, który również w 813 r. zebrał się w Tours. Ojcowie synodalni ubolewali w nim nad tym, że grzesznicy, których nieprawości kazirodztwo, zabójstwo, zabójstwo krewnych - były jawne, nie chcą słuchać kapłanów i trwają w swoim grzechu. Stwierdzali przeto, że należy ich odwieść od nieposłuszeństwa poprzez „dyscyplinę” świeckiej władzy. Referowany kanon czynił zatem niechęć do skłonienia uszu kapłańskim napomnieniom wraz z jawnym ignorowaniem biskupiej ekskomuniki podstawą do ingerencji świeckiej władzy ${ }^{46}$.

W tym więc momencie najpóźniej pokuta znalazła się w centrum zainteresowania politycznej elity. Poszły za tym kolejne kroki - gdyż regulacji domagał się najwyraźniej tryb zarządzania pokutami indywidualnymi. Deklarowanym celem podjętych działań stało się ożywienie tradycji pokuty publicznej - odprawianej w dawnym Kościele - jako rytu wykonywanego wobec wszystkich za grzechy publicznie popełnione ${ }^{47}$.

${ }^{44}$ Por. „It seems that the secular criminal courts retained, or were encouraged to retain, the Roman legal precept that the judge was to render his verdict according to written law, rather than exercise his own discretion. This principle was at odds with the numerous iterations in treatises on penance that the measure of penance was to be established by the priest's own judgement", A. Firey, op. cit., s. 194.

45 „Ut a domno imperatore impetretur adiutorium qualiter si quis publice peccat, publica multetur penitentia et secundum ordinem canonum pro merito suo et excommunicatur et reconcilietur", Concilium Cabillonense 813, wyd. w: MGH Concilia, t. 2, cz. 1: Concilia aevi Karolini pars I (742-817), wyd. A. Werminghoff, Hannoverae-Lipsiae 1906 (dalej: Conc. 2.1), c. 25, s. 278.

46 „Incestuosi, parricidae, homicidae multi apud nos, heu pro dolor, repperiuntur. Sed aliqui ex illis sacerdotum nolunt admonitionibus aurem accomodare, volentes in pristinis perdurare criminibus. Quos oportet per saecularis potentiae disciplinam a tam prava consuetudine coercere, qui per salutifera sacerdotum monita noluerunt revocari. Quorum aliquos iam excommunicavimus. Sed illi hoc parvipendentes in eisdem perdurant criminibus. Quamobrem vestra decernat mansuetudo, quid de talibus deinceps agendum sit", Concilium Turonense, Conc. 2.1, c. 41, s. 292.

${ }^{47}$ Por. M. de Jong, Transformations, s. 189; eadem, Pollution, Penance and Sanctity. Ekkehard's Life of Iso of St Gall, w: The Community, the Family, and the Saint. Patterns of Power in Early Medieval Europe. Selected Proceedings of the International Medieval Congress University of Leeds 4-7 July 1994, 10-13 July 1995, red. J. Hill, M. Swan, Turnhout 1998, s. 145-158; por. też B. Bedingfield, Public Penance in Anglo-Saxon England, „Anglo-Saxon England” 31, 
Rozróżnienie bowiem na grzechy publicznie popełniane, więc z publiczną pokutą, oraz niejawne, niejawnie wyznane, zatem i z pokutą niepublicznie za nie nakładaną, zadomowiło się w normatywnych tekstach owych dekad. Miało to związek ze swoistą karierą, jaką robił termin scandalum, m.in. na omawianych niżej synodach $813 \mathrm{r}^{48}$ Przykładem służy drugi kapitularz wspomnianego biskupa Orleanu Teodulfa (zm. 821) ${ }^{49}$. Zarazem zaakceptowano współistnienie pokuty publicznej z dobrze już zakorzenioną, w znacznym stopniu dzięki długotrwałemu wpływowi iryjskich duchownych, pokutą prywatną ${ }^{50}$.

W roku 813 sprawą zajęły się biskupie synody. W maju-czerwcu 813 r. odbyło się łącznie pięć takich zgromadzeń, w różnych częściach cesarstwa: w Arles, Reims, Moguncji, Chalon-sur-Saône i Tours. Być może biskupi dysponowali precyzyjnymi wskazówkami z dworu, o czym świadczyć miałaby względna jednolitość ustalonych kanonów, ze zbieżnościami we frazeologii włącznie ${ }^{51}$. Ale temat penitencjałów nie został potraktowany jednolicie. Synod w burgundzkim Chalon-sur-Saône potępił mianowicie księgi stosowane w związku z nakładaniem pokuty. Ojcowie synodalni określili je zgrabnie jako te, których błędy są pewne, za to autorzy - niepewni ${ }^{52}$. Kontekst dla tak ostrej krytyki stanowiło

2002, s. 226-227 - o tym, że pokuta publiczna znajdowała się w odwrocie i o próbach odwrócenia tej sytuacji przez karolińskich biskupów. Sarah Hamilton, The Practice of Penance 900-1050, Woodbridge 2001, s. 6, stawia odnośnie do pokuty publicznej w karolińskim ustawodawstwie pytanie: „reinvented or revived?”. Rob Meens, Remedies for Sins, s. 408, argumentując za „reinvented”, przypomniał, że pokuty publicznej w połowie VIII w. w ogóle nie wspominał w swoich tekstach Bonifacy. Mayke de Jong, Sacrum palatium et ecclesia. L'autorité religieuse royale sous les Carolingiens (790-840), „Annales. Histoire, Sciences Sociales” 58, 2003, 6, s. 1267, odnotowuje, że pokuta publiczna odrębna od „ukrytej” (occulte) nakładana przez kapłanów w związku ze scandalum pojawia się po raz pierwszy ok. 800 r. w tekstach powstających wokół dworu królewskiego.

${ }^{48}$ M. de Jong, Sacrum palatium, s. 1267.

49 Theodulfi [episcopi Aurelianensis] capitulare ad eosdem [sc. presbyteros], PL, t. 105, kol. 215 A (gdzie mowa o czynach homoseksualnych) oraz 215 D (o cudzołóstwie księży), stamtąd też szczególnie instruktywny cytat: „Adulterium si quis presbyter perpetraverit, sive palatum et publice cognitum, ab ordine sacerdotii cessabit, et publica poenitentia decem annorum purgabitur. Quod si occulte hoc fecerit, et occulte ad confessionem venerit, occulte ei poenitentia imponatur".

50 A.J. Frantzen, The Literature of Penance, s. 100.

${ }^{51}$ G. Schmitz, Die Reformkonzilien von 813 und die Sammlung des Benedictus Levita, „Deutsches Archiv für Erforschung des Mittelalters” 56, 2000, s. 2 oraz przypis 6 tamże - z przykładami zbieżności. Kilka miesięcy później, we wrześniu, opracowano collatio kanonów synodalnych, być może pomyślane jako podstawa dla wielkiego kapitularza. Ten jednak nie został nigdy wydany - najpewniej dlatego, że Karol Wielki zmarł w styczniu 814 r. - por. ibidem, s. 3.

52 ,[R]epudiatis ac penitus eliminatis libellis, quos penitentiales vocant, quorum sunt certi errores, incerti auctores", Concilium Cabillonense 813, s. 281, kanon (c.) 38. 
uprzednie stwierdzenie, iż miarodajnym źródłem w dziedzinie pokuty winny być święte kanony, względnie to, co można wywieść z Pisma Świętego lub zwyczaju ${ }^{53}$. Kanony synodu w Chalon wskazują też na to, że pokuty rekomendowane przez penitencjały były zbyt łagodne $e^{54}$.

Synod w Tours odniósł się do penitencjałów niejako na uboczu i w istocie inaczej. Zauważając, że w bardzo zróżnicowany sposób kapłani ustalają okres abstynencji (seksualnej w małżeństwie), będący elementem każdej pokuty, biskupi zasugerowali zwołanie do pałacu zgromadzenia całego episkopatu celem wskazania, który ze starych penitencjałów powinien być stosowany ${ }^{55}$. Nie ma tu zatem potępienia ksiąg ani praktyki ich wykorzystywania. Zaznacza się natomiast niepokój wywołany mnogością tekstów i sprzecznymi rozstrzygnięciami wydawanymi na ich podstawie. Uzasadnia to tezę Allena J. Frantzena, według którego trudno mówić w istocie o gremialnym potępieniu penitencjałów jako takich czy o próbie ich wykorzenienia. Kanon z synodu w Burgundii odzwierciedlać miał wyraziste poglądy bardzo wpływowego teologa - czyli obecnego już w moim tekście biskupa Teodulfa z Orleanu, dodatkowo, co tutaj nie bez znaczenia, człowieka wojującego z iryjskimi wpływami w ówczesnym życiu intelektualnym. Potępienie penitencjałów akurat w Chalon mogło też mieć związek z faktem, że północna Burgundia słynęła z kultywowania

Zatem: brak znanego autora należał do głównych kierunków ataku na synodach R. Kottje, Ehe und Eheverständnis in den vorgratianischen Bußbüchern, w: Love and Marriage in the Twelfth Century, red. W. van Hoecke, A. Welkenhuysen, Leuven 1981, s. 23.

53 „Modus autem penitentiae peccata sua aut per antiquorum canonum institutionem aut per sanctarum scripturarum auctoritatem aut per ecclesiasticam consuetudinem sicut superius dictum est, imponi debet...", Concilium Cabillonense 813, s. 281, c. 38. W cytacie nawiązanie (sicut superius dictum) do podobnych sformułowań, jeśli chodzi o źródło autorytetu z kanonu 34 ibidem, s. 280: „ut nullus sacerdotum umquam, aut gratia, aut odio alicuius personae, secus iudicet, quam quod in canonibus sacris invenerit aut quod illi secundum sanctarum scripturarum auctoritatem et eclesiasticam consuetudinem rectius visum fuerit". Allen J. Frantzen, The Literature of Penance, s. 98-99, wskazuje na ograniczenia bezpośredniego stosowania owych rekomendowanych źródeł w codziennej praktyce duszpasterskiej. Zdaniem Franza Kerffa, Libri paenitentiales, s. 55, termin consuetudo odnosi się do lokalnego, diecezjalnego prawa zwyczajowego.

54 „[Q]ui, dum pro peccatis gravibus leves quosdam et inusitatos imponunt paenitentiae modos", Concilium Cabillonense 813, s. 281, c. 38. Por. H. Lutterbach, Die mittelalterliche Bußbücher, s. 232 i przyp. 27: ten nurt krytyki penitencjałów da się prześledzić poza epokę ich powstawania, do Piotra Damianiego, z argumentem, że zbyt łagodna pokuta zagraża duszom (w domyśle ostatecznym potępieniem); R. Meens, Die Bußbücher und das Recht, s. 225.

55 „Ideo necessarium videbatur nobis, cum omnes episcopi ad sacrum palatium congregati fuerint, ab eis edoceri, cuius antiquorum liber paenitentialis potissimum sit sequendus", Concilium Turonense 813, Conc. 2.1, s. 289, c. 22. 
starych tradycji prawnych i tworzenia zbiorów kościelnego prawa (względem których rozstrzygnięcia w penitencjałach niekiedy jawiły się sprzecznymi $)^{56}$. Zresztą nie ma z okresu bezpośrednio poprzedzającego synody roku 813 śladów krytyki penitencjałów. Odnaleźć można za to statuty biskupów i zalecenia Karola Wielkiego wręcz sugerujące, że kapłan powinien posiadać, rozumieć i stosować penitencjały - jak w cesarskich Interrogationes examinationis z ok. 802-803 r. czy w wydanym ok. 805 r. zestawieniu materii, której kapłani winni się uczyćc ${ }^{57}$. Sam zaś Teodulf, zamieszczając w swoim drugim diecezjalnym kapitularzu rodzaj instrukcji dla spowiedników, rekomendował posiłkowanie się penitencjałami przy stawianiu spowiadającym się kolejnych pytańn ${ }^{58}$.

Bezpośrednio po synodach $813 \mathrm{r}$. temat penitencjałów nie był podejmowany. Wbrew rekomendacji z Tours nie zajmowano się nimi we wrześniu tegoż roku na ogólnym zgromadzeniu biskupów i możnych ${ }^{59}$.

W roku 829 na wezwanie następnego cesarza, Ludwika, odbyły się znów cztery synody (Tuluza, Lyon, Moguncja i Paryż) ${ }^{60}$. Zachowały się dokumenty czerwcowego synodu paryskiego, który zgromadził 16 hierarchów z północnych diecezji państwa Franków (dotrwały też urywki z synodu mogunckiego oraz zbiorcza relatio episcoporum, zapewne $z$ lipca 829) ${ }^{61}$. Za redaktora końcowych paryskich postanowień uchodzi biskup Jonasz z Orleanu, kolejna ważna postać życia kościelnego i intelektualnego tego czasu. Paryskie dokumenty budziły spore zainteresowanie $\mathrm{w}$ nauce $\mathrm{z}$ innych powodów. To pierwszy dowiedziony przykład zacytowania słynnego później fragmentu listu papieża Gelazego II

${ }^{56}$ A.J. Frantzen, The Literature of Penance, s. 99, 103; R. Kottje, Überlieferung und Rezeption, s. 522-523.

57 „[Interrogo vos, presbyteri] Benitentialem quomodo scitis vel intellegitis”, Interrogationes examinationis, MGH Capitularia 1, s. 234, pkt 3; „Paenitentialem”, Quae a presbyteris discenda sint, ibidem, s. 235, pkt 7. Por. A. Angenendt, T. Braucks, R. Busch, H. Lutterbach, op. cit., s. 31, a także A.J. Frantzen, The Literature of Penance, s. 100-102 - przykłady ze statutów biskupów Leodium Gerbalda (787-810) oraz Waltcauda (810-813), biskupa Haito z Bazylei (806-823), a także z diecezji fryzyngeńskiej z pierwszej połowy IX w.

58 O tym P.J. Payer, Sex and the Penitentials, s. 56; A.J. Frantzen, The Literature of Penance, s. 103.

${ }^{59}$ P.J. Payer, Sex and the Penitentials, s. 58.

${ }^{60} \mathrm{O}$ ich przygotowaniu, także o cesarskich dokumentach, które je poprzedzały i zapowiadały por. F.L. Ganshof, Am Vorabend der ersten Krise der Regierung Ludwigs des Frommen, „Frühmittelalterliche Studien” 6, 1972, s.46-48; M. de Jong, The Penitential State, s. 171.

${ }^{61}$ C. van Rhijn, M. Saan, Correcting Sinners, Correcting Texts. A Context for the Paenitentiale Pseudo-Theodori, „Early Medieval Europe” 14, 2006, 1, s. 35-36; F.L. Ganshof, op. cit., s. 50 . 
do cesarza bizantyjskiego Anastazjusza, w którym pojawia się doktryna dwóch władz ${ }^{62}$.

Synod paryski został określony jako „pokutny”. Jak pisała Mayke de Jong, kluczowym pytaniem, jakie zadawać sobie mieli biskupi, było to: jak my (w znaczeniu: społeczność chrześcijańska) obraziliśmy Boga? ${ }^{63}$ Biskupi zareagowali na cesarski list „przewodni”, w którym przedstawiono czarny obraz spraw: szerzenie się niesprawiedliwości, klęski (naturalne). Podkreślili skuteczność pokuty jako środka służącego odwróceniu gniewu Boga i uwypuklili niezastąpioną rolę episkopatu właśnie w tym obszarze. Biskupom bowiem wraz z niższym duchowieństwem przysługiwać miała funkcja pośredników między Bogiem a wiernymi, a ryty pokutne wraz z modlitwą uznawano za podstawowy środek, który należało wykorzystać. $\mathrm{W}$ istocie zresztą uprawnienia i autorytet biskupów (w tekście synodalnym używa się zgrabnej metafory: pondus sacerdotum) znalazły się w centrum uwagi zgromadzonych ${ }^{64}$. Synod zdefiniował biskupów jako grupę odpowiedzialną za ratowanie całego ludu Bożego, bo im przysługuje władza związywania i rozwiązywania ${ }^{65}$. Przy czym zgromadzeni zdobyli się też na refleksję nad grzechami własnej grupy, wymieniając ich całą listę i stwierdzając nawet, że lepiej nie mieć żadnego biskupa, niż biskupa winnego negligentia, zaniedbywania swoich obowiązków (te wątki rozważań tłumaczą, dlaczego też odwołano się do tekstów akwitańskiego retora z przełomu V i VI w., Julianusa Pomeriusa) ${ }^{66}$.

${ }^{62}$ Tytułem przykładu por. H.H. Anton, Zum politischen Konzept karolingischer Synoden und zur karolingischen Brüdergemeinschaft, „Historisches Jahrbuch” 99, 1979, s. 55-132, w tym bardzo obszerne przyp. 4, s. 55-58 i 5, s. 58-60 o frazach „gelazjańskich” w dokumentacji synodu w Paryżu z literaturą przedmiotu i dyskusją na ten temat.

63 O synodzie paryskim jako synodzie pokutnym: M. de Jong, The Penitential State, s. 176-183. Por. też eadem, Ecclesia and the Early Medieval Polity, w: Staat im frühen Mittelalter, red. W. Pohl, H. Reimitz, S. Airlie, Wien 2006, s. 130: „The synod of Paris was convened in order to identify the sins of the leadership and the people in order to pacify an offended God. According to a time-honoured tradition of Carolingian correctio, the synod of Paris aimed to combat confusio, trying to restore order by clarifying and re-imposing distinctions between ordines". O ideach synodu paryskiego także: C.M. Booker, Past Convictions. The Penance of Louis the Pious and the Decline of the Carolingians, Philadelphia 2009, s. 244. Inne ważne omówienie: S. Patzold, Episcopus. Wissen über Bischöfe im Frankenreich des späten 8. bis frühen 10. Jahrhunderts, Ostfildern 2008, s. 152-166.

${ }^{64}$ M. de Jong, The Penitential State, s. 182. Synod paryski stosował też - w kontekście jednak uprawnień instytucji Kościoła w zarządzaniu dobrami - termin canonica auctoritas, uprzednio traktowany jako synonim divina auctoritas / divina lex, teraz już będący w luźniejszym w związku z nim - por. H.H. Anton, op. cit., s. 66.

65 S. Patzold, Episcopus, s. 154.

${ }^{66}$ M. de Jong, Ecclesia, s. 131. Synod oddziałał na atmosferę intelektualną tych lat badacze odnotowują zaostrzenie w okresie między 829 a 833 r. relatywnie łagodnego 
W świetle powyższego przedstawienia bardziej zrozumiały staje się również paryski kanon 32, dotyczący penitencjałów ${ }^{67}$. Idzie on dalej niż decyzje sprzed 16 lat. Owe kłopotliwe książeczki (codicelli) odnoszące się do pokuty mają być zniesione. Ojcowie synodu bez ogródek przedstawili powody. Oto mianowicie liczni kapłani, po części z niedbałości, po części wskutek nieznajomości sposobów nakładania pokuty zawartych w kanonach, posługują się wobec wiernych owymi księgami zwanymi penitencjałami, napisanymi wbrew kanonicznemu autorytetowi. W rezultacie zaś nie leczą ran grzeszników, a tylko ich powierzchownie dotykają. Dlatego konieczne jest, aby każdy biskup w swojej diecezji pieczołowicie wyszukał pełne błędów książeczki i w ogień je wrzucił. Niechaj niedouczeni (imperiti) kapłani nie zwodzą już nimi dalej swoich wiernych $^{68}$. Dodatkowo kontekst dla owego zobowiązania nałożonego na biskupów stanowi zalecenie z sąsiedniego kanonu, ażeby biskupi regularnie objeżdżali swoje diecezje ${ }^{69}$. W innym miejscu tenże synod w Paryżu zobowiązał też biskupów, by instruowali kapłanów im podległych, jak należy wysłuchiwać spowiedzi, wypytywać o grzechy i określać pokuty ${ }^{70}$.

Zapisy wzbudzały w XIX i XX w. w nauce - pośród mediewistów, historyków pokuty, teologów - dyskusję. Odosobniony jest pogląd, zgodnie z którym ojcom synodalnym chodziło o wrzucenie w ogień wszelkich penitencjałów ${ }^{71}$. Jeśli dziś bywa on jeszcze powtarzany, to co najwyżej „inercyjnie”. Najprawdopodobniej w ogień miały być rzucone

języka admonicji kościelnych dokumentów poprzez odwoływanie się do terminów correptio, invectio - co widać np. w pismach arcybiskupa Lyonu Agobarda - C.M. Booker, Murmurs and Shouts, s. 352-353. Negligentia a odwoływanie się do Pomeriusa - por. Josh Timmermann, Sharers in the contemplative virtue: Julianus Pomerius's carolingian audience, „Comitatus. Journal of Medieval and Renaissance Studies” 45, 2014, s. 20-21.

${ }^{67}$ Concilium parisiense, MGH Concilia t. 2, cz. 2: Concilia aevi Karolini pars II (819842), wyd. A. Werminghoff, Hannoverae-Lipsiae 1908, s. 633, 829, kanon 32 pod następującym nagłówkiem: „ut codicelli, quos penitentiales vocant, quia canonicae auctoritatis referagantur, poenitus aboleantur".

68 ,[U]t unusquisque episcoporum in sua parochia eosdem erroneos codicellos diligenter perquirat et inventos igni tradat, ne per eos ulterius sacerdotes imperiti homines decipiant", ibidem.

${ }^{69}$ C. 31 z kluczowym zdaniem: „Statuimus etiam, ut tempore congruo unusquisquam parroechiam suam circumeat", ibidem, s. 633. Parrochia w tych kontekstach to oczywiście diecezja, nie parafia.

${ }^{70}$ Ogólnie o tym: A.J. Frantzen, The Literature of Penance, s. 99; R. Meens, Frequency and Nature, s. 37.

${ }^{71}$ Była to jedna z zasadniczych tez Rosamond Pierce, op. cit. Podobnie zdaje się te zapisy rozumieć P. Matwiejczuk, op. cit., s. 27, podkreślając zarazem, że kategoryczne podejście ojców synodalnych forsujących powrót do zapomnianej już na poziomie parafii pokuty kanonicznej rozbiło się o „lokalną, parafialną praktykę duszpasterską”. 
„tylko" penitencjały bez dowiedzionego autorytetu i uznane za sprzeczne $\mathrm{z}$ innymi kościelnymi przepisami ${ }^{72}$.

Nie zachowała się choćby wzmianka o paleniu penitencjałów. Nie wiadomo więc, czy i jak to zalecenie wykonywano. Świadectwo rękopisów sugeruje raczej, że nie tylko ich nie wypleniono, lecz wciąż były kopiowane, i to w tak centralnych ośrodkach karolińskiego życia kościelnego jak Sankt Gallen, Lorsch, Reims i Salzburg73. Zapis z 829 r. nie został też nigdzie i nigdy w kościelnym prawodawstwie powtórzony. Nie był „obudowany” dodatkowymi wyjaśnieniami ani też sankcją dla tych, którzy mieliby łamać zakaz wykorzystywania tego rodzaju pomocy. Sugeruje to, że biskupi w istocie nie planowali jakiejś rzeczywistej akcji wyszukiwania i niszczenia podejrzanych dzieł. Chcieli natomiast bardzo mocno zaznaczyć swoje stanowisko. Uzasadniona wydaje się opinia, że wszystkie te zalecenia miały na celu umocnienie władzy biskupów nad duchowieństwem parafialnym, a nawet nad działającymi w obszarze pokuty i dotąd posługującymi się owymi wątpliwymi księgami mnichami ${ }^{74}$. Zapis ten staje się też bardziej jasny, jeżeli - czego dla ostrożności raczej unikano - powiążemy działania z roku 829 w bezpośredni sposób z pracą biskupa Halitgara. Zdezawuowanie starych penitencjałów miało otworzyć wrota dla tekstu, który w duszpasterskiej praktyce zastąpiłby je wszystkie, będąc wolnym od wskazanej już, a zupełnie zasadniczej winy.

\section{Penitencjał Halitgara: problem autorytetu}

Halitgar, pasterz kościoła w Cambrai, sprawował swoją godność w latach 817-831. Szczegóły biografii nie są znane. Natomiast wiadomo o jego aktywnościach na pewnych istotnych polach, takich jak zaangażowanie w misję wśród duńskich Normanów ${ }^{75}$ oraz w dyskusje dotyczące kultu

72 Por. m.in. S. Hamilton, The Practice, s. 6.

73 Por. R. Meens, Frequency and Nature, s. 39; M. de Jong, The Penitential State, s. 182.

${ }^{74}$ M. de Jong, The Penitential State, s. 182.

$75 \mathrm{O}$ misji tak naprawdę niewiele wiadomo. Halitgara jako pomocnika Ebbona wspomina list papieża Paschalisa I do „wszystkich chrześcijan w krainach Północy” z 822 (lub 823) r., który wyznaczał hierarchę z Reims na papieskiego legata na północy ze szczególnymi uprawnieniami misyjnymi: Paschalis I, Epistola ad omnes Christianos ad partes Aquilonis, PL, t. 129, kol. 983 B-C: „Collegam denique huic divinae administrationis legationi ei providentes, Halitgarium religiosum adjicientes ministrum constituimus, quatenus ad sedem apostolicam opportuno valeat tempore de credito negotio facilius, praestante Domino, intimare et nunquam se in qualibet parte huic nostrae auctoritate ministerio commisso negligere”. O sprawie szerzej T.F.X. Noble, The Place in Papal History of the Roman Synod of 826, „Church History” 45, 1976, 4, s. 439-441, tamże przyp. 30, 
obrazów ${ }^{76}$. Swoje miejsce w hierarchii Kościoła frankijskiego zawdzięczał najpewniej bliskiej współpracy z arcybiskupem Reims Ebbonem. Pochwała uczoności Halitgara ze strony Ebbona w liście otwierającym omawiane poniżej dzieło nie musi być potraktowana jako topos w czystej postaci $^{77}$. Miała swoją wartość, zważywszy i na to, że sam Ebbo, postać nader kontrowersyjna ${ }^{78}$, cieszył się prestiżem z powodu swojej uczoności, nawet jeśli nie mógł się równać z takimi uznanymi intelektualistami we frankijskim episkopacie za Ludwika Pobożnego, jak wspomniany Jonasz z Orleanu czy też Agobard z Lyonu.

Halitgarowi przypisane zostało opracowanie zachowanych do naszych czasów biskupich kapitularzy, które miały wdrażać w pewnym zakresie zalecenia synodu w Paryżu na terenie jego diecezji. Zawierają one wskazówki dotyczące egzaminowania kapłanów ${ }^{79}$.

To na zlecenie hierarchy z Reims podjął się Halitgar skomponowania dzieła nader wszechstronnego. Stworzył traktat zatytułowany 0 cnotach $i$ wadach - w istocie utwór o tematyce wykraczającej poza to, co sugeruje sam tytuł ${ }^{80}$. Całość zawierała się w pięciu lub sześciu księgach -

s. 440: obrona identyfikacji wymienionego w liście Halitgara z biskupem Cambrai, a nie z nieznanym skądinąd klerykiem rzymskim tegoż imienia. Por. też Ch. Reuter, Ebbo von Reims und Ansgar. Ein Beitrag zur Missionsgeschichte des Nordens und zur Gründungsgeschichte des Bistums Hamburg, „Historische Zeitschrift” 105, 1910, 2, s. 237-284, zwłaszcza s. 255.

76 Por. M.E. Moore, A Sacred Kingdom, Bishops and the Rise of Frankish Kingship, 300-850, Washington D.C. 2011, s. 309 - w kontekście eksperckiej roli odgrywanej przez episkopat za rządów Karolingów; S. Patzold, Episcopus, s. 161.

77 Ebbo z Reims, Epistola Halitgario, w: MGH Epistolae 5, Epistolae Karolini aevi, t. 3, wyd. E. Dümmler, Berolini 1899, s. 616-617.

$78 \mathrm{O}$ nim por. m.in. P.R. McKeon, Archbishop Ebbo of Reims (816-835). A Study in the Carolingian Empire and Church, "Church History” 43, 1974, 4, s. 437-447; C.M. Booker, The False Decretals and Ebbo's fama ambigua. A Verdict Revisited, w: Fälschung als Mittel der Politik? Pseudoisidor im Licht der neuen Forschung. Gedenkschrift für Klaus Zechiel-Eckes, red. K. Ubl, D. Ziemann, Wiesbaden 2015, s. 207-242, w tym s. 216-222 ściśle o biografii.

79 W. Hartmann, Neue Texte zur bischöflichen Reformgesetzgebung aus den Jahren 829-831. Vier Diözesansynoden Halitgars von Cambrai, „Deutsches Archiv für Erforschung des Mittelalters" 35, 1979, s. 368-394, w tym 383-394 - edycja tekstu. Sceptycznie S. Patzold, Episcopus, s. 161, przyp. 407, według którego mógł owe statuty opracować każdy z 24 biskupów tworzących w 829 r. paryskie zgromadzenie. Teksty związane z egzaminowaniem kapłanów są tematem m.in. artykułu C. van Rhijn, „Et hoc considerat episcopus, ut ipsi presbyteri non sint idiothae". Carolingian Local Correctio and an Unknown Priests' Exam from the Early Ninth Century, w: Religious Franks. Religion and Power in the Frankish Kingdoms. Studies in Honour of Mayke de Jong, wyd. R. Meens et al., 2 wyd., Manchester 2016, s. $162-180$.

${ }^{80}$ Wydanie, do którego poniżej konsekwentnie się odwołuję: Halitgar, De vitiis et virtutibus et ordine poenitentium, w: H.J. Schmitz, Die Bussbücher und die Bussdisciplin der Kirche, t. 2, Mainz 1898 = Die Bussbücher und das kanonische Bussverfahren, s. 264-300. Nie 
poniżej wyjaśnienie, skąd się bierze owo zawahanie; kwestia to dla naszego tematu wręcz kluczowa. Pierwsza księga zawierała rozważania o ośmiu głównych grzechach, druga traktowała o życiu kontemplacyjnym i aktywnym, trzecia o porządku pokuty, czwarta omawiała grzechy świeckich (obficie wykorzystując wyciągi z kanonów synodów zwłaszcza w Ancyrze, Neocesarei i Bradze $)^{81}$, piąta - grzechy kleru. Traktat zatem w tych swoich partiach łączył teoretyczną refleksję z katalogiem przewin ludzi świeckich oraz duchownych, jak też z wypisami na temat kar kościelnych za te przewiny nakładanych. Źródłem norm były tu kanony synodów z wcześniejszych stuleci, znane Halitgarowi wskutek ich umieszczenia w dwóch bardzo ważnych kolekcjach prawa kanonicznego epoki pierwszych Karolingów - tzw. Dionysio-Hadriana, którą Karol Wielki miał w 774 r. przywieźć z Rzymu ${ }^{82}$, w Collectio Dacheriana, oraz w innym jeszcze zbiorze, określanym tytułem Canones Theodori ${ }^{83}$. Dodatkowo w częściach tych Halitgar wykorzystywał pastoralne teksty Augustyna, Grzegorza Wielkiego (np. Moralia in Iob) oraz autora dużo mniej znanego, ale wskutek pewnego historyczno-literackiego przypadku nader popularnego wśród karolińskich kościelnych intelektualistów, Juliana Pomeriusza ${ }^{84}$.

jest ono kompletne, ale wciąż pozostaje wyżej cenione od pełnego w: PL, t. 105, kol. 651710 - tamto jest powtórzeniem opartej na mniejszej liczbie rękopisów niż u Schmitza edycji Gallanda z 1779 r. Na temat wydań tekstu Halitgara por. R. Kottje, Die Bussbücher Halitgar von Cambrai und des Hrabanus Maurus. Ihre Überlieferung und ihre Quellen, BerlinNew York 1980, s. 144-148. Z przekładów tekstu źródłowego warto wspomnieć: polski (tekst dwujęzyczny obejmujący księgę szóstą), w: Libri poenitentiales / Księgi pokutne, red. A. Baron, H. Pietras, Kraków 2011, s. 315-331 oraz angielski w: J.T. McNeill, H.M. Gamer, op. cit. (1990), s. 297-314 (niekompletne).

${ }^{81}$ Por. omówienie jej surowych zaleceń związanych z małżeństwem w: R. Kottje, Ehe und Eheverständnis, s. 28-29, 31-32.

82 Por. R. Kottje, Einheit und Vielfalt des kirchlichen Lebens in der Karolingerzeit, „Zeitschrift für Kirchengeschichte" 76, 1965, s. 335. Powstanie Dionysio-Hadriana łączono z Dionizjuszem Exiguusem. Zbiór upowszechnił się na początku IX w. we wszystkich częściach państwa Franków. H. Mordek, Kirchenrechtliche Autoritäten, s. 252, uznaje jego propagowanie za przejaw tendencji do ujednolicenia standardów prawnych i liturgicznych w Kościele karolińskim, która to tendencja dominowała za Karola Wielkiego - później miała być kontestowana przez obrońców prowincjonalnych kościelnych tradycji.

${ }^{83}$ R. Kottje, Die Bussbücher, s. 181-182.

${ }^{84}$ Autor ten, współczesny Cezariuszowi z Arles, często był mylnie cytowany pod imieniem Prospera z Akwitanii, a popularność w kręgach karolińskiego episkopatu zawdzięczał w znacznym stopniu swojej tezie, zgodnie z którą rzetelnie wykonujący swoje obowiązki biskup może osiągnąć moralną doskonałość - por. na ten temat: J. Timmermann, op. cit., s. 1-44. W istocie źródeł Halitgar miał więcej - na przykład w jego definicji czterech cnót kardynalnych zauważalny jest wpływ Alkuina - por. L. Wallach, Alcuin on Virtues and Vices. A Manual for a Carolingian Soldier, „The Harvard Theological Review" 48, 1955, 3, s. 190-191. 
Do pięciu ksiąg dołączona została szósta, o wyraźnie innym charakterze. Choć nie w całej rękopiśmiennej tradycji Halitgara ona się pojawia, nie kwestionuje się raczej poglądu, że od początku należała do zrębu, któremu postać nadał biskup Cambrai ${ }^{85}$. Halitgar napisał w przedmowie otwierającej cały traktat, że nie jest ona wynikiem jego trudu wypisywania (ze źródeł), lecz wydobyta została z zasobów rzymskiego Kościoła (,de scrinio romanae ecclesiae"; choć od słowa scrinium pochodzi polskie skrzynia, tu uzasadnione będzie tłumaczenie nie aż tak konkretne: „zasób” względnie „archiwum”) ${ }^{86}$. Dalej Halitgar przedstawił szczególne przeznaczenie owej szóstej księgi. Oto służyć ma ona prostszym umysłom, które większych rzeczy pojąć nie są w stanie ${ }^{87}$. Jest przy tym jasne, że owi docelowi czytelnicy czy też odbiorcy dzieła to kapłani, a osobliwie wyróżniona wśród nich przez autora kategoria to kapłani uważani przez Halitgara za czy to niedouczonych, czy mało pojętnych. W przedmowie bezpośrednio już do księgi szóstej biskup ujął cel jej dołączenia do traktatu łagodniej, wskazując, że ułatwi ona szybkie znalezienie informacji o pokucie za konkretne grzechy ${ }^{88}$.

Szósta księga Halitgara w swojej strukturze jest niczym innym, jak penitencjałem. Bez przywoływania źródeł w poszczególnych rozdziałach - wyróżnia się ich 104 lub 105 - wylicza przewinienia, które opatruje rekomendowanymi pokutami. Miarę pokuty stanowi długość narzuconego postu. W innym miejscu dzieła Halitgara znalazło się skądinąd dopuszczenie zamiany postu na inną formę pokuty (czyli komutacja). W księdze można wyróżnić trzy części - ów podział nakreślili badacze; nie pochodzi on od średniowiecznego twórcy, redaktora bądź kompilatora czy był nim sam Halitgar, czy ktoś inny ${ }^{89}$. Rozdziały od 1 do 54 zawierają

85 Por. R. Kottje, Die Bussbücher, s. 159-160, 164; w starszej literaturze m.in. R. von Nostitz-Rieneck, Zum Bußbuch Halitgars von Cambray, „Zeitschrift für katholische Theologie" 20, 1896, 3, s. 567.

86 „Sextus quoque ponitur libellus de paenitentia qui non est ex labore nostre excerpsionis sed adsumptus de scrinio romanae ecclesiae in quo multa ac diversa continentur, quae in canonibus non habentur", Halitgar, De vitiis, s. 266.

${ }^{87}$ „Tamen simplicioribus qui majora non valent capere poterit prodesse”, ibidem, s. 266.

${ }^{88}$,[U]t si forte he prolate sententie alicui superfluum sunt visae aut penitus que desiderat ibi de singulorum criminibus nequiverit invenire, in hac saltem brevitate novissima omnium scelera forsitan inveniet explicate", ibidem, s. 290. O tenorze obu przedmów i rodzaju zachęty do użytkowania księgi szóstej por. R. Nostitz-Rieneck, op. cit., s. 568.

${ }^{89} \mathrm{Na}$ ten temat: P. Fournier, Études sur les Pénitentiels, cz. 4: Le livre VI du pénitentiel d'Halitgar, „Revue d'histoire et de littérature religieuses” 8, 1903, 6, s. 528-553; L. Körntgen, Studien zu den Quellen der frühmittelalterlichen Bussbücher, Sigmaringen 1993, s. 87 n.; C. Vogel, Les Libri Paenitentiales, s. 81. 
materiał pochodzący z penitencjału wiązanego z Kolumbanem, kombinowany $\mathrm{z}$ kanonami synodalnymi. Utrzymano tu tradycyjny, iryjski porządek rzeczowy jeśli chodzi o grzechy: zabójstwo - cudzołóstwo - krzywoprzysięstwo - kradzież - maleficio (magia) - świętokradztwo (jest tam sporo o praktykach dających się odnieść do kultu pogańskiego, niekiedy z rozbudową czy doprecyzowaniem dawnych zapisów, definicji $\left.{ }^{90}\right)$. Ów pomysł na strukturę w epoce karolińskiej pozostawał ciągle atrakcyjny w związku z żywością refleksji nad ośmiu grzechami głównymi - obecnej skądinąd w innej części dzieła Halitgara, a inspirującej choćby już ojców synodalnych z Chalons, którzy zalecali, by penitenta odpytywać podczas spowiedzi właśnie według tego schematu. Przepisy różne (45-54) poprzedzają te poświęcone grzechowi pijaństwa, otwierające już kolejny segment. Dalsze bowiem punkty: 55-77 pochodzą z tzw. penitencjału Kummeana z VII w. Z kolei konstytuujące trzecią partię punkty 78-105 mają pochodzenie niepewne czy też mocno mieszane. Inaczej niż w zbudowanych w podobny sposób i nieodległych czasowo penitencjałach Sangallense tripartitum i Merseburgense, nie można ich powiązać $\mathrm{z}$ ważnym źródłem jakim były Iudicia Theodori ${ }^{91}$. Ludger Körntgen przekonywał, że to tzw. Paenitentiale Oxoniense II - tekst skompilowany jeszcze w połowie VIII w. w północno-wschodniej części królestwa Franków, a budzący duże zainteresowanie badaczy jako osobliwie „humanitarny” w swoich zapisach, był bezpośrednim źródłem trzeciego bloku kanonów ${ }^{92}$. Istotną przesłanką wydaje się tutaj fakt, że w tej części - w szczególności od punktu 86 - post $\mathrm{z}$ reguły jest odmierzany w tygodniach, nie w latach ${ }^{93}$. Pośród źródeł penitencjału z dzieła Halitgara wymienia się nadto zbiór znany jako Iudicia Canonica, kanony synodu w Ancyrze, ekscerpowane dwie inne księgi pokutne (jedna to niezachowane źródło dla Sangallense tripartitum, druga znana jest fragmentarycznie z rękopisu D1 z Düsseldorfu). Należy zatem zgodzić się ze stwierdzeniem, że ów penitencjał godził tradycje iryjskich ksiąg pokutnych ze śródziemnomorskimi tradycjami prawa

90 Por. J.T. McNeill, Folk-Paganism in the Penitentials, „The Journal of Religion” 13, 1933, 4, s. 458.

${ }^{91}$ L. Körntgen, Studien, s. 87.

92 Ibidem, s. 90; tabela konkordancji między „rzymskim penitencjałem Halitgara", Oxoniense II i pokrewnymi penitencjałami, s. 115-116 pokazuje, że ponad połowa zapisów z Oxoniense II trafiła do szóstej księgi Halitgara. Według Körntgena Oxoniense II powstał jako praktyczny poradnik dla kleru diecezji z północno-wschodniej części królestwa Franków, treściowo i literacko integralny, napisany przez przedstawiciela duchowieństwa świeckiego - i dlatego wyprany z monastycznego kontekstu iryjskich penitencjałów i ich surowości, natomiast po części odzwierciedlający germańskie praktyki prawne - ibidem, s. 120, 138-154, 200.

93 Por. P. Fournier, op. cit., s. 546. 
kanonicznego ${ }^{94}$. Charakterystyczne, że kompilacja, którą stanowi szósta księga Halitgara, zestawiona została bez istotnej ingerencji w strukturę i treści materiału źródłowego - podczas gdy w księgach od drugiej do piątej Halitgar przepracował swój materiał, ułożył go systematycznie ${ }^{95}$.

Powyższa bardzo skrótowa prezentacja pokazuje, że nie jest to bynajmniej penitencjał „rzymski”. Całą jego treść można wywieść z kręgu iryjskiego bądź frankijskiego ${ }^{96}$. Tego rodzaju połączenia upowszechniały się zresztą - pod postacią tzw. tripartita, penitencjałów zbudowanych z materiałów pochodzących z Irlandii, Anglii i kontynentu. Skądinąd zaś w stolicy chrześcijaństwa penitencjały jako takie zjawiły się późno, nigdy nie odgrywały roli ani też w konsekwencji nie budziły specjalnych kontrowersji ${ }^{97}$.

Otwarta pozostaje kwestia, czy trudu kompilacji dokonał sam Halitgar, czy też biskup ów „znalazł” względnie dostał gotowy lub prawie gotowy tekst i dołączył go do pięciu pozostałych, też w sumie kompilatorskich ksiąg. Mocne argumenty przywoływane są na rzecz drugiego stanowiska. We fragmentach, w których zapowiada treść szóstej księgi, Halitgar nie tylko wypiera się swojego autorstwa, ale też dystansuje się niejako od jej poziomu ${ }^{98}$. Kierunek myślenia wyrażony w penitencjale nie do końca jest zbieżny z tym w pozostałych księgach. Jak wspomniano, nie została ułożona w systematycznej manierze - tak jak to się stało z materiałem w księgach ją poprzedzających. W istocie odnaleźć w niej można owe wyklinane defekty wcześniejszych penitencjałów: anonimowość wykorzystanych źródeł, sprzeczność zaleceń. Cytowany już badacz, Körntgen, sugerował powstanie „penitencjału rzymskiego” w takiej właśnie postaci, jaką znamy z De vitiis, krótko przed działalnością Halitgara - choć nie zachowały się rękopisy, które mogłyby tego dowieść ${ }^{99}$. W każdym razie nieprawdopodobne się wydaje, ażeby hierarcha z Cambrai uzyskał

94 R. Meens, Frequency and Nature, s. 40.

95 L. Körntgen, Studien, s. 244-245.

${ }^{96}$ P. Fournier, op. cit., s. 550; R. Kottje, Die Bussbücher, s. 158; idem, Ehe und Eheverständnis, s. 23; R. Meens, The Historiography of Early Medieval Penance, w: A New History of Penance, s. 76.

${ }^{97}$ A.J. Frantzen, The Literature of Penance, s. 104 - odnotowuje względnie późne rekomendowanie stosowania penitencjałów przez papieża Mikołaja I (858-867).

${ }_{98}$ Por. „With these remarks Halitgar was able to distance himself from the composition of what is in truth a traditional type of penitential depending on older penitential sources and to give to his sixth book the authority which would come from its association with the Roman Church", P.J. Payer, Sex and the Penitentials, s. 66; por. R. Meens, The Historiography, s. 77.

${ }^{99}$ L. Körntgen, Studien, s. 89, 192. Zdaniem badacza sam Halitgar nie znał penitencjału Oxoniense II i przejął jego treści w gotowej już kompilacji, która stała się szóstą księga jego traktatu - ibidem, s. 245. 
tekst w samym Rzymie lub choćby uwierzył w którymkolwiek momencie w informację o takiejże jego genezie. Raczej wolno zakładać, że miał świadomość co do prawdziwego źródła przepisów i intencjonalnie posłużył się fikcją rzymskiego pochodzenia po to, by wprowadzić tę nową kompilację do obiegu w uprzywilejowanej pozycji.

Kluczowe znaczenie miało bowiem powiązanie tekstu z uniwersalnym i niehistorycznym jedynie autorytetem. Jednym ze skutków działań Karola Wielkiego i jego „reformatorskiego” kręgu stało się awansowanie do tej roli papieskiego Rzymu. „Z Rzymu” miały przecież pochodzić wprowadzana odgórnie standaryzowana liturgia, muzyka czy zbiory kanonów ${ }^{100}$. Możliwe jest również, że reformatorzy IX w. szczerze poszukiwali jakiejś autentycznej rzymskiej tradycji w kwestii pokuty.

Fikcja „rzymskości” przyjęła się zresztą. Pod tym mianem penitencjał z dzieła Halitgara miał być przywoływany w dwóch bardzo ważnych tekstach nowej epoki kościelnego prawodawstwa, Reginona z Prüm z końca IX w. i Burcharda $\mathrm{z}$ Wormacji z przełomu tysiącleci $-\mathrm{u}$ tego ostatniego nazywany jest wręcz „penitencjałem rzymskich biskupów” 101. Jako „rzymski" był też przedmiotem krytyki, gdy formuła penitencjałów stawała się już skądinąd anachroniczna. Wtedy zresztą podważono jego „rzymskość”.

Wyposażenie traktowanego jako całość dzieła Halitgara w wymagany z punktu widzenia jego celów autorytet dokonuje się na kilku poziomach. Z jednej strony tekst nie jest anonimowy. Jego twórcą był biskup, postać w założeniu obdarzona nie tylko władzą, ale i autorytetem właśnie (pamiętajmy, że są to właściwości bynajmniej nie równoznaczne i niekoniecznie się nakładające). Drugi poziom określa zleceniodawca: głowa ważnej kościelnej prowincji. Księgi Halitgara zazwyczaj kopiowano wraz z listem Ebbona i krótszą odeń odpowiedzią Halitgara. Wynikało to nie tylko z poszanowania dla oryginalnej postaci tekstu - co nie było przecież stałym przymiotem średniowiecznych kopistów. Ci, którzy księgi biskupa Cambrai przeznaczali do dalszego stosowania i je przepisywali lub przepisanie zlecali, widzieli w liście Ebbona przede wszystkim dodatkowe utwierdzenie ich autorytetu. Trzeci poziom to omówiona wyżej

100 Por. H. Mordek, Kirchenrechtliche Autoritäten, s. 241-242 o merowińskim już, jak też karolińskim powoływaniu się na „rzymskość” dla nadania autorytetu kościelnym rozstrzygnięciom. Por. „Rome was a treasure trove of sacred resources into which the new Frankish rulers tapped more effectively and systematically than their predecessors - not purely tactically, but also religiously", M. de Jong, Ecclesia, s. 118; R. Kottje, Einheit, s. 327.

${ }^{101} \mathrm{O}$ penitencjale Burcharda - jednej z ksiąg jego traktatu Liber corrector - por. m.in. L. Körntgen, Fortschreibung frühmittelalterlicher Bußpraxis. Burchads „Liber corrector” und seine Quellen, w: Bischof Burchard von Worms. 1000-1025, red. W. Hartmann, Mainz 2000, s. $199-226$. 
fikcja rzymskiego pochodzenia księgi szóstej. Poziom czwarty dotyczy ksiąg poprzedzających szóstą, w których wskazywane są ich źródła, czyli dicta patrum dla księgi drugiej, decyzje synodów dla księgi trzeciej, kościelni autorzy o dużej powadze - Augustyn, Grzegorz Wielki czy Prosper z Akwitanii (w istocie Julian Pomeriusz) dla księgi pierwszej ${ }^{102}$. „Penitencjał rzymski”, jako pochodzący zgodnie z deklaracją Halitgara z samego serca chrześcijaństwa, takiego wskazania wykorzystanych źródeł w jego przekonaniu już nie wymagał.

Owa piętrowość autorytetów okazała się zresztą z perspektywy samego Halitgara też pewnym problemem, skoro w przedmowie poczuł się zmuszony do dokonania wyważenia między nimi i uwypuklił w zdecydowany sposób rangę kościelnej tradycji oraz tych, którzy przed nim ją zebrali, mocno umniejszając swoją rolę i określając siebie jako tego, który (tylko) ekscerpuje. Wskazywał przy tym, że jego skromne imię nie powinno skłaniać do lekceważenia tekstu, skoro stoi za nim autorytet ojców ${ }^{103}$. Było to bezpieczne wyjście. Z perspektywy autora oraz jego czytelników tradycji należało się pierwszeństwo przed dokonaniami współczesności. Na tym jednak swoiste wyważanie autorytetów u Halitgara się nie kończy. Gdzie indziej musiał bowiem na przekór owemu samouniżeniu pośrednio odwołać się do podparcia, jakie zapewniało jego imię i godność. Uczynił to w przedmowie do samej księgi szóstej, gdzie przyznał, że nie zna twórcy penitencjału pochodzącego (rzekomo) ze scrinium rzymskiego Kościoła, a jednak zdecydował się na jego dołączenie po to, by czytelnik łatwiej odnajdywał wiadomości odnoszące się do konkretnych grzechów ${ }^{104}$. Jawnie sugerowana tym razem przez samego Halitgara anonimowość (,a quo sit editus, ignoramus”) księgi niweluje do pewnego stopnia pozytywny efekt informacji o „rzymskości” i wykorzystanie tekstu, nadanie mu autorytetu wymaga dodatkowego argumentu. W ostatecznym rozrachunku odbiorca, przyjmując „rzymski penitencjał" jako źródło wiedzy i, co kluczowe, podstawę własnych rozstrzygnięć, zawierza rozeznaniu biskupa Cambrai Halitgara. Na nim

102 Bezpośrednia zapowiedź ich wykorzystywania: Halitgar, De vitiis, s. 266.

103 „Hanc autem epistolam nemo quidem existimet meam, ne illi pro parvitate nominis nec villescat sed sciat a majoribus nostris ex sanctorum sententiis esse collectam a me quidem excerptam ne nimia prolixitate negligentibus lectoribus fastidium generaret", ibidem, s. 266.

104 „Addidimus etiam huic operi excerptionis nostrae paenitentialem romanum alterum quod de scrinio romane ecclesie adsumpsimus, attamen, a quo sit editus, ignoramus. Idcirco adnectendum prescriptis canonum sententiis decrevimus, ut si forte he prolate sententie alicui superfluum sunt visae aut penitus que desiderat ibi de singulorum criminibus nequiverit invenire, in hac saltem brevitate novissima omnium scelera forsitan inveniet explicate", ibidem, s. 290. 
i na jego instytucjonalnym umocowaniu ogniskuje uwagę użycie w omawianym fragmencie pierwszej osoby liczby mnogiej.

Dodać trzeba, że w przypadku wcześniejszych penitencjałów zdarzało się wskazywanie źródeł - acz nie tak znów regularne. W historii poszczególnych tekstów pojawiały się też atrybucje autorskie będące takimi samymi mistyfikacjami, jak rzymskie repozytorium w przedmowie Halitgara. W żadnym nie wystąpiły jednak wszystkie wymienione tutaj poziomy. Każe to spojrzeć na tzw. penitencjał Halitgara od strony celów przyświecających nie autorowi, ale środowisku.

Jak wspomniano, ścisłe określenie daty powstania tekstu nie jest możliwe. Mieści się ona w całym okresie biskupich rządów Halitgara w Cambrai: 817-831. Do rozważenia są wszakże zasadniczo dwie opcje. Traktat został napisany po synodach 829 r. i pod wpływem postanowień z Paryża ${ }^{105}$ lub też przygotowywany był wcześniej, gdyż Ebbo i Halitgar chcieli lub spodziewali się przyjęcia decyzji dotyczących pokuty w znanym nam dziś z materiałów paryskich kształcie. Gdyby tak było, to od razu po potępieniu dawnych libelli możliwe stawało się przedstawienie alternatywy, wolnej - zdaniem Ebbona i Haltigara - od wad penitencjałów do tego czasu znajdujących się w obiegu.

Taki scenariusz jest możliwy. Pośredniej wskazówki dostarcza list Ebbona. Hierarcha z Reims pisze o tym, że owe zamierzone wypisy z kanonów miały złożyć się na penitencjał - którego sam nie był w stanie opracować - „ad opus consacerdotum nostrorum” ${ }^{106}$. Kluczowe jest tu rozumienie słowa consacerdos. Sacerdos mógł oznaczać i kapłana, i biskupa. To drugie znaczenie w epoce, o której mowa, stawało się coraz częstsze. Pytanie zatem polega na tym, czy Ebbo chciał skomponować penitencjał z myślą o potrzebach naszych braci w kapłaństwie, czy naszych braci w godności biskupiej (metaforyczne braterstwo przywołujemy w propozycji przekładu, by uniknąć sztucznie brzmiącego dosłownego tłumaczenia: współbiskup, współkapłan). Ponieważ penitencjałów nie wiązano z codziennymi obowiązkami biskupa, narzucałoby się owo bardziej

105 Za powstaniem dzieła Halitgara ok. 830 - po Paryżu - opowiedział się A.J. Frantzen, The Literature of Penance, s. 103. Jeżeli Halitgar był twórcą odkrytych i wydanych przez Wilfrieda Hartmanna czterech statutów diecezjalnych powstałych po Paryżu, do jego własnego traktatu regulującego pokutę nawiązuje być może punkt drugi trzeciego statutu - W. Hartmann, op. cit., s. 387, Capituli de synodo tertio, II: „ut circa animarum vobis commissarum salute magnopere laborare satagatis tam in paenitentiis dando quamque et in reconciliatione iuxta modem canonice institutionis, quem vobis verbis et scriptis contradidi".

106 „Idcirco, ut tecum contuli, ex partum dictis canonumque quoque sententiis, ad opus consacerdotum nostrorum excerpere paenitentialem minime valui", Ebbo z Reims, Epistola Halitgario, s. 616. 
„demokratyczne" rozumienie - mowa o kapłanach diecezji Reims czy Cambrai, którzy dla swoich zwierzchników są nostri consacerdotes. Do rozważenia jest też wszakże rozumienie „elitarne”. Ebbonowi chodzić mogło o innych członków galijskiego episkopatu. Zamierzony penitencjał miał im posłużyć pomocą - nie w tym sensie, iżby sami mieli go na co dzień stosować wobec penitentów, lecz w tym, że mogli go narzucić kapłanom w swoich diecezjach. Rzecz dalej rozwijając, wprowadzaliby w ten sposób jednolite standardy nie tylko i nie przede wszystkim w nakładanych pokutach, lecz w rycie pokuty oraz zasadach jej nakładania czy przyjmowania rekoncyliacji - o czym mowa poniżej, gdyż owe ważne elementy znalazły się w dziele Halitgara.

W każdym razie rozstrzygnąć, czy Ebbo i Halitgar działali z wyprzedzeniem i przygotowywali dzieło z nadzieją na jego zaaplikowanie w innych prowincjach kościelnych cesarstwa zaraz po synodach $829 \mathrm{r}$., czy też może jednak działali „reaktywnie”, w odpowiedzi na decyzje synodalne, dziś się nie da ${ }^{107}$. Jeśli bowiem istniał plan narzucenia własnej propozycji w tym zakresie, nie doszło do żadnej odzwierciedlonej w źródłach próby jego realizacji. Mogła się do tego przyczynić sytuacja polityczna, jaka wytworzyła się w miesiącach bezpośrednio po synodzie paryskim - o czym jeszcze będzie niżej mowa.

Związek między powstaniem i kształtem penitencjału Halitgara a zaleceniami władz kościelnych z tamtych lat dotyczącymi pokuty jest niezaprzeczalny ${ }^{108}$. Widać to już na etapie definiowania jego celów. Tu znowu można się odwołać do listu Ebbona. Zabrzmiały w nim wątki znane z cytowanych wyżej tekstów synodalnych wczesnego IX w. Arcybiskup wyraża więc to samo zatroskanie prowadzącymi do konfuzji rozstrzygnięciami pokutnymi w książeczkach, którymi posługują się kapłani (tu już bez wątpienia chodzi o „szeregowych” kapłanów). Wspomina o braku autorytetu, który by stał za owymi książeczkami i przywołuje wizję powodowanej przez nie (w życiu Kościoła, wiernych) dysharmonii ${ }^{109}$. Sprawa zaś szkodzi najbardziej tym, którzy zabiegają o lekarstwo pokuty ${ }^{110}$.

107 Por. R. Kottje, Die Bussbücher, s. 5.

108 A.J. Frantzen, The Literature of Penance, s. 104 o dziele Halitgara: „No previous or subsequent - handbook was its equal in meeting both the theoretical and the practical demands of private penance".

109 „Et hoc est, quod in hac re me valde sollicitat, quum ita confusa sunt iudicia penitentum in presbyterorum nostrorum opusculis, atque ita diversa et inter se discrepantia et nullius auctoritate suffulta, ut vix propter dissonantiam possint discerni", Ebbo z Reims, Epistola Halitgario, s. 616.

110 „Unde fit, ut concurrentes ad remedium paenitentiae tam pro librorum confusione quam etiam pro ingenii tarditate nullatenus eis valeant subvenire", ibidem. 


\section{Penitencjał Halitgara: \\ najistotniejsze zagadnienia}

Dalej w niniejszym artykule używany będzie niekiedy termin reforma lub reformatorski. Tak zwykło się bowiem określać m.in. wybrane penitencjały IX w. (Halitgara, Hrabana Maura, anonimowe Quadripartitus oraz Pseudo-Teodor). Akcentuje się w ten sposób ich związek z karolińską polityką daleko idących zmian we wszystkich sferach działalności Kościoła. Od razu jednak trzeba poczynić pewne zastrzeżenie. Teoretycy i decydenci epoki nie chełpili się bynajmniej wprowadzaniem innowacji. Powołując się na dawne synody czy pisma Ojców Kościoła, przekonywali raczej, że odkrywają to, co albo było stanem pierwotnym, albo też od początków dziejów Kościoła zawsze było postulowane. Sensem ich poczynań pozostawało zatem odnowienie, nie zaś nowość; odnalezienie, nie zaś wynalezienie. Tekst Halitgara - w pełnej postaci, nie tylko owa najczęściej eksploatowana we współczesnej nauce szósta księga z „rzymskim” penitencjałem, ujawnia kilka tematów, których postawienie i przeforsowanie w warunkach państwa Franków i funkcjonującego w nim Kościoła było dla reformatorów nadzwyczaj istotne. Należy je przedstawić.

Pierwsza sprawa to rygorystyczne określenie uprawnień w dziedzinie administrowania pokutą. Kto miał pokutę nakładać? Kto zaś - uznawszy ją za odprawioną - dopuszczać grzesznika na powrót do wspólnoty wiernych? Halitgar zdecydowanie podkreśla, że tylko kapłan z pełnymi święceniami (prezbiter) może przyjąć wyznanie win i naznaczyć pokutę ${ }^{111}$. Pokazuje też sytuacje nadzwyczajne, gdy wystąpić może kapłan z niższymi święceniami (diakon). Tenor całości pozostaje wszakże jednoznaczny. Administrowanie pokutą od tej strony to jedna z prerogatyw określających ekskluzywizm stanu kapłańskiego. Ta grupa stanowiła grono adresatów kanonów synodalnych, tekstów takich jak traktat Halitgara oraz statutów biskupich (jakich całkiem spora liczba z tamtych właśnie dekad się zachowała). Kościelna elita uznała za ważne uporządkowanie edukacji kapłanów, zadbanie o jej wysoki standard, a dalej - objęcie ich działań kontrolą ${ }^{112}$. Jednym $\mathrm{z}$ aspektów wzmożonego zainteresowania

111 „Non enim omnes Clerici hanc scripturam usurpare et legere debent, nisi Episcopi et Presbyteri, quibus claves regni coelorum traditi sunt, sic nec iudicia ista alii usurpare debent", ibidem, s. 291.

${ }^{112} \mathrm{Na}$ ten temat m.in. monografia Carine van Rhijn, Shepherds of the Lord. Priests and Episcopal Statutes in the Carolingian Period, Turnhout 2007, passim; także tejże uczonej: Priests and the Carolingian Reforms. The Bottlenecks of Local Correctio, w: Texts and Identities, s. 219-238. Autorka podkreśla przełomowość działań karolińskiego episkopatu - por. np. ibidem, s. 220 o statutach Teodulfa, ale też o podobnych biskupich 
życiem kapłanów była też troska o (rytualną) czystość przy udzielaniu sakramentów. Kapłan miał być stale gotowy do wykonywania czynności związanych z sakramentami ${ }^{113}$, stąd też tyle uwagi $\mathrm{w}$ penitencjale Halitgara poświęca się kwestiom czystości. W zamian natomiast biskupi działali na rzecz symbolicznego i praktycznego wyniesienia tej grupy ponad świeckich, ponad osoby z niższymi święceniami. Znajdowało to wyraz w naznaczaniu odrębnych, coraz wyższych pokut za te same czyny dla kolejno: diakonów, prezbiterów i biskupów (zgodnie z zasadą, że więcej im dano, toteż więcej się od nich wymaga) ${ }^{114}$.

Osobna kwestia pośród kluczowych dla Halitgara zagadnień to przeprowadzanie rekoncyliacji. Halitgar napisał, iż dopuszczenie grzesznika po odbytej pokucie do wspólnoty chrześcijańskiej nie może się odbywać bez akceptacji biskupa - poza koniecznością, czyli sytuacjami, gdy biskupa nie ma ${ }^{115}$. Rekoncyliację organizowano w tamtej epoce zwykle w Wielki Czwartek ${ }^{116}$. Taka ceremonia obejmowała zapewne zazwyczaj od razu większą grupę penitentów. Biskupi, zastrzegając sobie prawo do oceny, czy poszczególny pokutnik może zostać uznany za uwolnionego od pokuty (na skutek jej dopełnienia), zyskiwali też kontrolę nad całym procesem. Innym jej przejawem było w pełni zrozumiałe z perspektywy pragmatyki dominującej w naszej własnej epoce zalecenie, ażeby w sytuacjach bardziej skomplikowanych definitywne naznaczenie czasu pokuty

tekstach - a powstało ich w tej epoce do początku X w. ponad 50: „Before, say, 800, hardly any detailed attention had ever been devoted in the Latin West to the local secular clergy at all, let alone in such an elaborate way". Ta sama autorka wskazuje na znaczną swobodę poszczególnych biskupów w realizacji ramowych zaleceń synodów, np. w kwestii edukacji duchownych: C. van Rhijn, The Local Church, Priests' Handbooks and Pastoral Care in the Carolingian Period, w: Chiese locali e chiese regionali nell'alto medioevo, Spoleto, 4-9 aprile 2013, Spoleto 2014, s. 703; także eadem, „Et hoc considerat, s. 164, 167, 172. O zadaniach, jakie stawiano przed kapłanami szczególnie w obszarze pokuty: asystowanie, pomoc, pokierowanie „wewnętrznym sądem sumienia” każdego grzesznika, pisał ostatnio np. C.M. Booker, Hypocrisy, s. 201. Zawężanie kręgu uprawnionych do sprawowania pokuty omawia m.in. F. Kerff, Libri paenitentiales, s. 28-29.

113 C. van Rhijn, Priests, s. 222-223.

114 Por. Halitgar, De vitiis, s. 294 nn. Z drugiej strony wyraziło się to też w zaleceniu, by prezbitera czy diakona winnego pewnych ciężkich przewinień usunąć ze stanu kapłańskiego, lecz równocześnie nie pozbawiać komunii, gdyż nie powinno się karać podwójnie: „Presbiter aut diaconus in fornicatione aut perjurio aut furto aut homicidio captus est, deponatur nec tamen communione privetur; dicit enim scriptura, non judicabit dominus bis in idipsum", ibidem, ks. V, c. IIII, s. 288.

115, ,U]t presbyter inconsulto episcopo non reconciliet poenitentem, nisi absentia episcopi necessitate cogente”, ibidem, ks. 3, r. XI, s. 277; także ks. 3, r. XII, s. 278.

116 „[Q]uinta feria ante Pascha eis remittendum Romanae Ecclesiae consuetudo demonstrat", ibidem, ks. 3, r. XIII, s. 278 - poza nagłymi sytuacjami. 
pozostawić jednak decyzji biskupa ${ }^{117}$. Dla porównania, wykorzystywany prawdopodobnie przez Halitgara frankijski już penitencjał Oxoniense II z połowy VIII w. dopuszczał nakładanie pokut przez biskupa lub prezbitera nie przeciwstawiając, a nawet poniekąd uznając ich swoistą równorzędność, podczas gdy dość konsekwentnie wykluczał diakonów z nakładania pokut czy dopuszczania do rekoncyliacji ${ }^{118}$. Halitgar poszedł tu w kierunku oddzielenia roli biskupa i kapłana.

Kontrola, o której mowa, rozciągała się w intencjach kościelnych autorów poza akt rekoncyliacji. Oto bowiem Halitgar śladem wcześniejszych tekstów (sam przywołuje bezpośrednio rozstrzygnięcie papieża Leona I) dodatkowo nakłada surowe ograniczenia na tych, którzy już odpokutowali swoje wcześniejsze grzechy - nakazując im bezterminowe powstrzymanie się od handlu, od aktywności wojskowej i, co najważniejsze, od małżeństwa i życia seksualnego ${ }^{119}$. Świadomość istnienia tych zaleceń, tak łatwych do obejścia, stwarzała od razu problem. Halitgar dodał, że łamiących zakaz można dopuścić do mszy, lecz nie do komunii ${ }^{120}$. Jak jednak wyglądało praktyczne egzekwowanie ograniczenia i jak uchybienia w przestrzeganiu zakazów oraz w egzekucji kary dodatkowej wpływały na autorytet lokalnych biskupów? Wydaje się, że właśnie tutaj kryło się szczególne niebezpieczeństwo. Powszechność obchodzenia prawa rujnuje przecież prestiż każdej stojącej za nim władzy.

O ile potwierdzenie roli prezbiterów w nakładaniu pokuty wynikało z praktycznych potrzeb i oznaczało równocześnie definitywne zaakceptowanie pokuty prywatnej $\mathrm{w}$ formie, jaka się rozwinęła pod iryjskim wpływem, o tyle uznawane przez Halitgara rozstrzygnięcia dotyczące rekoncyliacji przywracały czy tylko potwierdzały obecność w życiu Kościoła elementu pokuty publicznej, nawiązującego bezpośrednio do znanych tradycji pierwszych wieków. Biskupi autor używa zresztą określeń publica/secreta satisfactio, a miarą jego ustępstw wobec współczesnej

117 „Ut poenitentibus secundum differentiam peccatorum episcopi arbitrio poenitentiae tempora decernantur”, ibidem, ks. 3, r. XI, s. 277. Por. F. Kerff, Libri paenitentiales, s. 29-30: w tym samym kierunku szły współczesne statuty biskupów Gerbalda z Leodium i Herarda z Tours.

118 Por. L. Körntgen, Studien, s. 161-162; M. Kieling, op. cit., s. 235-236; R. Meens, Frequency and Nature, s. 40 przyp. 30 - podkreślenie kanonicznych źródeł rozstrzygnięcia u Halitgara: decyzje synodu w Kartaginie recypowane via zbiór Dacheriana.

119 „Quod penitenti nulla lucra negotationis exercere conveniat”, Halitgar, De vitiis, ks. 3, r. VI; „Contrarium est omnino ecclesiasticis regulis, post poenitentiae actionem redire ad militiam saecularem", ibidem, ks. 3, r. VII.

${ }^{120}$ Ibidem, ks. 3, r. VIII, s. 276: ci, którzy po pokucie wracają jak pies do wymiocin (metafora za drugim listem św. Piotra, 2,22) m.in. do militiae cingulum, ludicras voluptates, nova conjugia - mają być dopuszczeni wprawdzie do mszy, ale nie do komunii. 
praktyki jest stwierdzenie z przedmowy, że nie zaprzecza, ażeby prywatna satisfactio była wystarczająca nawet w przypadku grzechów śmiertelnych ${ }^{121}$. Rekomenduje wszakże w przypadku grzechu publicznego i powszechnie znanego, takiego, który poruszył Kościół, dopełnienie rekoncyliacji na zewnątrz budynku kościoła, w domyśle: w obecności wiernych ${ }^{122}$.

Można się oczywiście zastanawiać, czy w praktyce biskupi zawsze byli w stanie (mogli, chcieli) egzekwować te uprawnienia, w szczególności przy rekoncyliacji obejmującej znaczną liczbę wiernych. Tego rodzaju wątpliwości znajdują się w tle tez historyków zaprzeczających upowszechnieniu się spowiedzi (i generalnie - rytu pokutnego) wśród mas wiernych w interesującej nas tutaj epoce. Zwolennicy tego poglądu widzą w tekstach normatywnych ambitny program, który długo jeszcze pozostawał daleki od możliwości jego zrealizowania. Negują powszechność jego wdrażania w praktyce ${ }^{123}$.

W każdym razie zapisy umieszczone przez Halitgara porządkowały kompetencje. Mimo obecności we wcześniejszym okresie głosów w tej sprawie, rzecz wciąż wymagała autorytatywnego utwierdzenia. Penitencjał wydany pod imieniem biskupa wydawał się dobrą drogą, komplementarną wobec kanonów i statutów.

Druga sprawa wiąże się z wprowadzeniem do traktatu Halitgara scenariusza przebiegu pokuty - czyli tego, co zwykło się określać mianem ordo poenitentiae (w liczbie mnogiej ordines). Poświęcona mu została trzecia księga ${ }^{124}$. Ta część dzieła hierarchy z Cambrai zawiera sekwencję liturgicznych czynności i przytacza rekomendowane modlitwy. Wcześniejsze penitencjały obywały się bez ordines. Było to możliwe, skoro kapłani mogli odwołać się do sakramentarzy - np. sakramentarza gelazjańskiego.

121 „Secreta quoque satisfactione solvi mortalia crimina non negamus”, ibidem, s. 266.

122 „Cujuscunque autem poenitentis publicum et vulgatissimum crimen est, quod universam Ecclesiam commoverit, ante absidam manus ei imponatur", ibidem, ks. 3, r. XI, s. 277. Wzmiankowane w tekście nałożenie ręki (na grzesznika przez kapłana) symbolicznie reprezentuje cały ryt rekoncyliacji. Jako źródło owego rozwiązania wydawcy wskazują kanony synodu z Kartaginy z V stulecia - istotnie byłoby to zatem nawiązanie do praktyki Kościoła sprzed kilku wieków. Skądinąd zdaniem Cyrille’a Vogela działania reformatorów karolińskich zaowocowały zaistnieniem faktycznie trzech odmian pokuty: paenitentia publica solemnis, paenitentia publica minus solemnis, paenitentia privata - C. Vogel, Les Libri Paenitentiales, s. 43.

123 A. Murray, op. cit., s. 26. Przeciwnie - m.in. D. Bachrach, op. cit., s. 5-6.

${ }^{124}$ W cytowanym wydaniu Schmitza: Halitgar, De vitiis, s. 270-273 - odnośnie do wyznania win, żalu grzesznika i nałożenia pokuty, natomiast na s. 273-275 - scenariusz rekoncyliacji. Na ten temat m.in. H. Lutterbach, Die Bußordines, s. 152, 154-155. 
Umieszczenie razem wszystkich tekstów odnoszących się do pokuty było u Halitgara przemyślanym krokiem. Wskazywało na głębszą refleksję „na górze" kościelnej hierarchii nad realiami duszpasterstwa. Poszczególne modlitwy zamieszczone przez Halitgara nie były natomiast owocem inwencji autora. Zostały zaczerpnięte ze wspomnianego sakramentarza gelazjańskiego i z tzw. Mszału z Bobbio ${ }^{125}$. Także w ramach wcześniejszych od Halitgarowego penitencjałów już do nich nawiązano. To samo dotyczy ważnej instrukcji dla spowiedników, od pierwszych swoich słów określanej jako Quotiescunque. Powstała ona w VIII w. i była dołączana do różnych penitencjałów - u Halitgara otwiera księgę VI traktatu, czyli penitencjał właściwy ${ }^{126}$.

Trzeci wątek łączy się bezpośrednio z poprzednim i zwracał też już uwagę badaczy. W ramach ordo penitentiae Halitgara podkreślona zostaje konieczność odpowiedniej postawy ze strony kapłana. Modlitwy i gesty, które każe mu się wykonywać, podkreślają jego współuczestnictwo w grzechu (w sensie bycia obarczonym taką samą grzeszną naturą) oraz $\mathrm{w}$ pokucie. Kapłan razem $\mathrm{z}$ penitentem wykonuje gesty prostracji i zalewa się łzami ${ }^{127}$. Modlitwa przezeń odmawiana łączy go z grzesznikiem. Dołącza się do wyznania winy wygłaszanego przez tego ostatniego. Deklaruje, że sam jest niegodny. Nie tylko kieruje aktem pokutnym, ale w nim sam bardzo czynnie ma uczestniczyć. Pierwsze słowa Quotiescunque zachęcają duszpasterzy do wspólnego z penitentami poszczenia - przez tydzień, dwa lub ile mogą, z powołaniem na Ewangelię św. Łukasza 11,46, gdzie napiętnowano faryzeuszy, którzy nakładają brzemiona na innych,

125 A.J. Frantzen, The Literature of Penance, s. 105; B. Bedingfield, op. cit., s. 227.

${ }^{126}$ Halitgar, De vitiis, s. 290. Była drugą częścią przedmowy do penitencjału Oxoniense II i wykorzystały ją penitencjały frankijskie na nim bazujące - L. Körntgen, Studien, s. 130-131. Od IX w. dołączanie ordines rytu pokuty do penitencjału staje się regularne - C. Vogel, Les Libri Paenitentiales, s. 32. Rob Meens, Remedies for Sins, s. 415, łączy to z obecną od IX w. tendencją do szczegółowego ujmowania na piśmie wszystkiego, co pokuty dotyczy. Por. także o rozwijających się w okresie karolińskim rytach przeprowadzania pokuty: A.H. Gaastra, „Between Liturgy and Canon Law. A Study of Books of Confession and Penance in Eleventh- and Twelfth-Century Italy" (Ph.D., University of Utrecht 2007), https://dspace.library.uu.nl/handle/1874/23216 (dostęp: 15 VIII 2019), s. 136 nn. Instrukcja Quotienscunque jako źródło rytu u Halitgara oraz jego łącznik z dawną kościelną tradycją - por. H. Lutterbach, Die Bußordines, s. 161-162, tamże s. 155-160 bliższe jej omówienie; także A.H. Gaastra, „Between Liturgy”, s. 126. Por. też przedstawienie pokutnych rytuałów z próbą uwzględnienia perspektywy ich uczestników: S. Hamilton, The Unique Favour of Penance. The Church and the People c.800-c.1100, w: The Medieval World, wyd. P. Linehan, J.L. Nelson, M. Costambeys, (2 wyd.) London-New York 2006, s. 229-243.

127 „Tunc sacerdos cum poenitente prostratus cum luctu et gemitu dicat”, Halitgar, De vitiis, s. 272. 
a sami palcem nie kiwną ${ }^{128}$. Dodatkowe uzasadnienie stanowi przyrównanie roli biskupa czy kapłana względem grzesznika do roli lekarza' ${ }^{129}$. Jest to metaforyka, która w tym gatunku literackim miała długą tradycję, jej zastosowanie wszakże u biskupa Cambrai należy do najbardziej wyrafinowanych ${ }^{130}$. Dodatkowo Halitgar wskazywał, że przykład zbolałego kapłana dopomaga $w$ skrusze penitenta ${ }^{131}$. Miało to niemałe znaczenie, skoro bardzo istotna z perspektywy obecnej w pokutnym ordo Halitgara była skrucha autentyczna, zamanifestowana łzami grzesznika ${ }^{132}$.

Te aspekty tekstu Halitgara wiodły do poglądu, zgodnie z którym biskup Cambrai przemycił niejako w swoim dziele rodzaj podręcznika do ćwiczeń duchowych mających na co dzień formować kapłanów ${ }^{133}$. Jak jednak dalece nie sięgałyby w tej sferze wyobrażenia i zamiary Halitgara, w dokonanym przezeń zestawieniu i wyborze modlitw oraz czynności liturgicznych dochodzi do głosu świadomość ryzyka, jakie niosła za sobą rutyna w obszarze udzielania sakramentu. Pokuta dla karolińskich (jak też dla wcześniejszych czy późniejszych) kościelnych autorów nie była po prostu jedną z procedur. Miała rozbudowane uzasadnienie teologiczne. Stąd też zaskakujące dla późniejszego czytelnika rozważania w tekście Halitgara na temat wartości, jaką przynosi wyznanie swoich win wobec samego Boga, bez pośrednictwa kapłana. Jeśli jest autentyczne i rzetelne, ma taką samą wartość, co spowiedź uszna - Halitgar idzie tu zresztą tropem $\mathrm{np}$. wspominanego współczesnego mu synodu

128 „Quotiescunque Christiani ad penitentiam accedunt jejunia damus et nos communicare cum eis debemus jejunio unam aut duas septimanas aut quantum possumus", ibidem, s. 290.

129 „Nemo autem potest sublevare cadentem sub pondere nisi inclinaverit se, ut porrigat ei manum: neque ullus medicorum vulnera infirmantium potest curare, nisi foetoribus particeps fuerit: ita quoque nullus sacerdotum vel pontifex peccatorum vulnera curare potest, aut animabus peccata auferre, nisi praestante sollicitudine et oratione lacrymarum", ibidem, s. 291.

130 Por. J.T. McNeill, Medicine for Sin as Prescribed in the Penitentials, „Church History” 1, 1932, 1, s. 14-26, o dziele Halitgara - s. 22; H. Lutterbach, Intentions-oder Tathaftung?, s. 142.

${ }^{131}$ Halitgar, De vitiis, s. 291-292. Por. A.J. Frantzen, The Literature of Penance, s. 106: „The ordo [z dzieła Halitgara] posed the priest as a model for the penitent”; S. Hamilton, The Practice, s. 40.

132 H. von Soden, op. cit., s. 112, 114.

133 Por. G. Fort, Penitents and Their Proxies. Penance for Others in Early Medieval Europe, „Church History” 86, 2017, 1, s. 19, w kontekście odgrywania przez duchownych roli zastępców w odprawianiu pokuty: „we must see the penitentials not only as lists of crimes and satisfactory acts but also as clerical manuals of spiritual care, albeit in a nascent form. To say that these texts were primarily judicial, or controlling, or educational is to miss those moments when they encourage proxy activity and thereby evince their emotional range". 
w Chalon-sur-Saône ${ }^{134}$. Przy tego rodzaju sposobie myślenia perspektywa rutynowego, pozbawionego odczuwania, mechanicznego prowadzenia przez prezbiterów działań wobec grzeszników jawiła się jako realna groźba. Konieczne stawało się swoiste zaszczepienie kapłanów przed tego rodzaju niebezpieczeństwem. To również przeto należy zaliczyć do celów, które przyświecały dziełu Halitgara.

Powiązany z rozwijaną wyżej kwestią pozostaje z kolei wątek domniemanego „humanizmu” (czy może: humanitaryzmu) w dziele Halitgara. Termin w tym kontekście nawiązuje oczywiście do opinii wyrażonych swego czasu przez Pierre'a J. Payera ${ }^{135}$. Kanadyjski badacz sugerował, że w (niektórych) penitencjałach frankijskich VIII i IX w. wyraźnie pojawiło się ujęcie, które pozwalało zauważyć obok grzechu również grzesznika, a zorientowane było nie na samo rozliczenie czy wyrównanie szkody, którą spowodowały złe uczynki, lecz na moralną poprawę człowieka. Payer zatem nie zgadza się z ryczałtowym niejako we wcześniejszych analizach penitencjałów zarzutem automatyzmu i ignorowania indywidualności grzesznika. Tekst Halitgara również został wykorzystany w jego argumentacji. Bo też u Halitgara w tym kierunku zdają się prowadzić pewne sformułowania z przedmowy. Stoją one nawet w niejakiej sprzeczności z ogólną zasadą dołączonego jako szósta księga „rzymskiego" penitencjału. Oto bowiem autor stwierdza, że synodalne kanony (z których będzie czerpać w dalszej części) nie ustanawiały (w domyśle sztywnych, rygorystycznych) miar czasu (w domyśle: na odpokutowanie) za grzech, zostawiając ustalenie wymiaru pokuty kapłanowi. Było tak, gdyż dla Boga liczy się miara bólu (wewnętrznego człowieka), nie zaś miara czasu (spędzonego na pokutowaniu). I dalej czytamy: mniej liczy się poszczenie grzesznika, a bardziej uśmiercenie jego grzechów ${ }^{136}$. Stwierdzenia owe mają swoje podparcie w kościelnym myśleniu o pokucie. W tekstach pojawia się bowiem nieraz zalecenie zdawania się w konkretnych przypadkach na rozum lub rozeznanie duszpasterza - tak bowiem chyba najlepiej tu oddać łaciński termin discretio. Halitgar przynajmniej werbalnie pozostaje w nurcie tej samej tradycji. Zacytowane

134 Por. Concilium Cabillonense 813, c. 33, s. 280: spowiedź uczyniona samemu Bogu tak samo wartościowa jak ta wobec księdza. Na temat odpowiedniego fragmentu Halitgara por. H. von Soden, op. cit., s. 112, przyp. 399.

135 P.J. Payer, The Humanism of the Penitentials and the Continuity of the Penitential Tradition, „Mediaeval Studies” 46, 1984, s. 340-354.

136 „Mensuram autem temporis in agenda poenitentia idcirco non satis attente praefigunt canones pro unoquoque crimine, sed magis in arbitrio antistitis relinquendum statuunt, quia apud Deum non tam valet mensura temporis quam doloris. Nec abstinentia tantum ciborum, sed mortificatio potius vitiorum", Halitgar, De vitiis, s. 266. 
jednak zdanie, o genezie łączącej je ze zbiorem kanonów dziś znanym jako Collectio Dacheriana ${ }^{137}$, nieprzypadkowo sformułowane zostało w czasie przeszłym. Dalej piszący uwypukla bowiem użyteczność - z punktu widzenia wdrażania kanonów - tego, że z czasem dla niektórych grzechów naznaczono konkretne miary pokuty ${ }^{138}$. Istniała w końcu przecież obawa, że spowiednicy mogliby nadużywać tej swobody - stąd synod paryski przestrzegał kapłanów przed nakładaniem pokuty przez wzgląd na (otrzymane) dary, miłość, strach czy jakieś (oczekiwane) łaski ${ }^{139}$.

Domniemane złagodzenie tradycyjnego rygoryzmu iryjskich penitencjałów wykazuje część ostatnia penitencjału. Jak wspomniano, występują w niej posty liczone w tygodniach, nie w latach. Byłby to ślad użytkowania Oxoniense II. Gdy jednak przychodzi do określania pokut za morderstwa i kradzieże, kompilator „rzymskiego penitencjału” z dzieła Halitgara preferuje surowsze wskazania. W interesującym nas dziele nie odnajduje się też śladu najbardziej swoistej części wspomnianego penitencjału Oxoniense II - pierwszej części jego prologu, gdzie otwarcie skrytykowano nadmierne pokuty nakładane przez duszpasterzy, uznając je za jeden z powodów wstrzymywania się przez wiernych od przystępowania do sakramentu $^{140}$. Można tu dodać, iż Thomas P. Oakley, który wyróżniał trzy tradycje, jeśli chodzi o zalecane pokuty: najstarszą i najbardziej rygorystyczną iryjską, późniejszą, mniejszościową, raczej łagodną oraz kompromisową, umieszczał Halitgara bliżej „bieguna surowości”141.

137 P.J. Payer, The Humanism, s. 346 - badacz ilustruje w tym miejscu tezę, że w przypadku penitencjałów tamtej epoki za „humanitarne” tendencje odpowiadał nierzadko zewnętrzny materiał, który zdecydowali się oni wyzyskać. U Halitgara obok przedmowy z Dacheriana podobnie oddziałała instrukcja Quotienscunque. Penitencjałem, któremu łatwiej przypisać „humanitarne” tendencje - ze względu na tenor przedmowy, indywidualizację pokut - jest późniejszy nieco penitencjał Pseudo-Grzegorza III; o nim F. Kerff, Das Paenitentiale Pseudo-Gregorii III. Ein Zeugnis karolingischer Reformbestrebungen, „Zeitschrift der Savigny-Stiftung für Rechtsgeschichte", Kanonistische Abteilung 69, 1983, s. 46-63.

138 „Exstant tamen pro quibusdam culpis modi paenitentiae in canonibus inpositi, iuxta quos cetere perpende sunt culpe, cum sit facile per eosdam modos vindictam et censuram canonum aestimare", Halitgar, De vitiis, s. 266.

139 „Sacerdotes porro, qui aut muneris aut amoris aut timoris aut certe favoris causa tempora modumque paenitentiae ad libitum paenitentium indicunt, audiant", i dalej, mocniejsza jeszcze przestroga: „Praesbyteri etiam imperiti sollerti studio ab episcopis suis instruendi sunt, qualiter et confitentium peccata discrete inquirere eisque congruum modum secundum canonicam auctoritatem paenitentiae noverint imponere, quoniam hactenus eorum incuria et ignorantia multorum flagitia remanserunt inpunita et hoc ad ruinam animarum pertinere dubium non est", Concilium parisiense, r. 32, s. 633.

140 Por. L. Körntgen, Studien, s. 205.

141 Por. T.P. Oakley, Alleviations of Penance in the Continental Penitentials, „Speculum” 12, 1937, 4, s. 495. 
Zagadnieniem pokrewnym, o którym warto wspomnieć, jest relacja między modyfikacjami wprowadzanymi w obszarze pokuty przez Halitgara i biskupią politykę jego okresu, a tradycjami prawnymi współkształtującymi życie społeczności wiernych. Wskaźnikiem jest tutaj stosunek kościelnej elity do zemsty rodowej ${ }^{142}$. Na synodzie paryskim z $829 \mathrm{r}$. biskupi otwarcie przestrzegali przed nieprawnym odwoływaniem się do zemsty (vindicta), jako zagrażającym rozlewem krwi. W ich wezwaniu brak wyraźnych aluzji do prawa zwyczajowego, natomiast w duchu, który nieobcy był cesarskim kapitularzom, podkreślone zostało zło wypływające $z$ uzurpowania sobie prawa do sięgania po przemoc i mszczenia na własną rękę swoich osobistych krzywd ${ }^{143}$.

Kolejny ważny aspekt dzieła Halitgara to usankcjonowanie praktyki komutacji. Niezbyt długa, lecz pogłębiona refleksja nad funkcjonowaniem pokuty taryfikowanej ujawnia jeden z jej najpoważniejszych potencjalnych defektów. Skoro za każdy pojedynczy grzech jako pokuta przewidziane były posty liczone w latach, niezwykle łatwo było dorobić się dziesiątek lat postów do odbycia. Niewykonalność tych zaleceń rzucała się w oczy ${ }^{144}$. Problem był w pewnym stopniu pokrewny konsekwencjom systemu kompozycji przewidzianego w zwyczajowym prawie germańskim, gdzie określana autorytetem prawa wysokość wergeldów i kar kompozycyjnych przerastała z pewnością możliwości płatnicze ogromnej

${ }^{142}$ Do tego tematu por. np. G. Austin, Vengeance and Law in Eleventh-Century Worms. Burchard and the Canon Law of Feuds, w: Medieval Church Law and the origins of the western legal tradition. A Tribute to Kenneth Pennington, red. W.P. Müller, M.E. Sommar, Washington D.C. 2006, s. 71, z tezą: do czasów Burcharda z Wormacji Kościół, także w penitencjałach, łagodniej traktował zabójstwa uznane za realizację zemsty. Por. też T.P. Oakley, The Cooperation, s. 522-523.

143 „Econtra vero nescimus, qua pernoxia adinventione a nonnnullis usurpatum est, ut hi, qui nullo ministerio fulciuntur, propter sua odia et diversissimas voluntates pessimas indebitum sibi usurpant in vindicandis proximis et in interficiendis hominibus vindictae ministerium et, quod rex saltim in uno exercere debeat propter terrorum multorum, ipsi inpudenter in multis perpetrare non metuunt propter odium et putant sibi licere ob inimicitiarum vindictas, quod nolunt, ut rex faciat propter Dei vindictam", Concilium parisiense, r. 84 (17), s. 675-676, tu 676.

144 Por. C. Vogel, Composition légale et commutations dans le système de la pénitence tarifée, „Revue de droit canonique” 8, 1958, 4, s. 299 wraz z przypisem 37: przy takich pokutach (długie i surowe posty za pojedyncze wykroczenie, zwłaszcza w dziedzinie seksualnej) życia by nie starczyło na wywiązanie się z nich; były one zatem nie do zaaplikowania, choć z innych powodów aniżeli pokuta antyczna; ponadto pokuta taryfikowana stawała się trudna do zastosowania z uwagi na długość i skomplikowanie rytu. Por. też spostrzeżenie w A. Murray, op. cit., s. 27: „Laws too harsh for observance produce two effects. One is that the policeman becomes legislator, having to decide, since all break the law, on when to inflict punishment. The second effect is commutation". 
części sądzonych sprawców ${ }^{145}$. Podobnie rzecz się miała z pokutami, a zdaniem anonimowego twórcy Oxoniense II z połowy VIII w. nakładanie zbyt surowych pokut wręcz zniechęcało wiernych ${ }^{146}$.

Już zatem od czasów iryjskich przyzwalano na formy zastępcze. Należały do nich genuflexio (klęczenie), msze, psalmy, jałmużny. Zachowały się nawet całe gotowe tabele komutacyjne - jak na przykład lista z klasztoru w Tallagh z drugiej połowy VIII w. ${ }^{147}$ Dopuszczano też zastępców wykonujących pokutę pod postacią postu, ale czasem także modlitw, zamiast i w imieniu penitenta ${ }^{148}$. Istniała tradycja, zgodnie z którą modyfikacji pokuty - w tym okresu jej trwania - dokonać mógł biskup ${ }^{149}$. Rzecz budziła kontrowersje i wymagała regulacji. Halitgar zatem również musiał się do niej odnieść. Komutacja została zaakceptowana. Pojawił się przelicznik. Jeśli ktoś nie mógł pościć, a był bogaty - za każde siedem tygodni naznaczonego postu powinien uiścić 20 solidów jałmużny, 10 zaś

145 Analogię między systemem pokuty taryfikowanej a stosowaniem kompozycji (tak charakterystycznej dla praw zwłaszcza germańskich) podkreślał Cyrille Vogel, Composition, s. 294: „une analogie entre la taxation des fautes et les amendes minutieusement calculées de la compositio légale soit indéniable”. Jest to jednak analogia, natomiast zdaniem tegoż autora nie występował między owymi systemami związek w praktyce funkcjonowania pokuty, nawet jeśli iryjscy normodawcy stosowali miary zaczerpnięte z prawa „świeckiego” czy dołączali w penitencjałach do pokuty np. kwotę wypłacaną rodzinie zhańbionej przez grzesznika cudzołóstwem panny czy wdowy (tzw. pretium pudicitiae). Penitencjały kontynentalne i anglosaskie nie nakładały pokut z zakresu compositio, bo uznawano to za prerogatywę władzy publicznej, nie spowiednika, ibidem, s. 301-302, 306, 313. Gdy jednak pokutnik nie był w stanie wywiązać się z wymogu zapłacenia nałożonej też na niego za ten sam czyn przez świecki sąd compositio, kanony dopuszczały zwiększenie dokładnie z tego powodu wymiaru jego pokuty ibidem, s. 317.

146 Por. L. Körntgen, Studien, s. 162, s. 198.

147 O tabelach komutacyjnych m.in. H. Lutterbach, Die mittelalterliche Bußbücher, s. 231 - zwracając uwagę na fizyczny - cielesny - i kwantytatywny charakter zamienników; por. przypis 23 tamże: „Während sich der Ermessenspielraum des Beichtvaters allerdings in der Alten Kirche allein auf die Individualität des Sünders inklusive der für seine Tat maßgeblichen Umstände bezogen hatte, beschränkte er sich im Frühmittelalters weitgehend auf die möglichst exakte Bemessung des Schadens". W tradycji iryjskiej komutacja w formie jałmużny szczególnie często występowała w związku z pijaństwem i wykroczeniami seksualnymi, choć post pozostawał i tak najważniejszy A. Angenendt, T. Braucks, R. Busch, H. Lutterbach, op. cit., s. 34. Na temat komutacji por. też m.in. T.P. Oakley, Commutations and Redemptions of Penance in the Penitentials, „The Catholic Historical Review" 18, 1932, 3, s. 341-351, w tym s. 343: wyrażenie wątpliwości, czy wszystkie penitencjały dopuszczały komutacje oraz co do uniwersalności praktyki.

148 Ostatnio na ten temat: G. Fort, Penitents, s. 1-32, z podkreśleniem, że takim optymalnym zastępcą był kapłan odprawiający msze.

${ }^{149}$ C. Vogel, Composition, s. 291-292; uwaga - mogło to być także tzw. superpositio, superimpositio - zaostrzenie postu np. w formie jego wydłużenia - ibidem, s. 296. 
czy 3 solidy wtedy, jeśli był biedniejszy ${ }^{150}$. Do tegoż tematu przynależy nadto inna regulacja, zgodnie z którą jeśli ktoś umarł pod ekskomuniką, krewni mogą złożyć dar na ołtarzu na wykupienie jeńców za niego „ad commemorationem animae ejus" ${ }^{151}$. Rodzina zatem dopełnia ofiarą pokutę, której, jak się zakłada, wyłączony ze wspólnoty Kościoła nie zdążył odprawić. Są to mimo wszystko zapisy bardzo ramowe i powstaje wrażenie, że biskup uchylił się od rozwinięcia tematu. Nie odniósł się do nadużyć, których ryzyko kryło się w ogóle w dopuszczeniu tego rodzaju zastępczych form czy w pokutowaniu „za kogoś” ${ }^{152}$. W tym obszarze po prostu jego penitencjał godzi się z zastanymi realiami. Najistotniejsze wszakże wydawało się tutaj uprawomocnienie praktyki przez tekst roszczący sobie pretensje do bycia autorytatywnym ${ }^{153}$.

\section{Jakie zadanie wypełnić miało dzieło Halitgara?}

Po przedstawieniu zasadniczych zagadnień warto wrócić do pytania, jak by się wydawało, oczywistego i z oczywistą odpowiedzią. Komu i do czego w zamierzeniu Halitgara i Ebbona dzieło tego pierwszego miało służyć? Niechaj za punkt wyjścia zostanie uznana hipoteza jednego ze specjalistów w badaniach nad księgami pokutnymi, Franza Kerffa. Jego zdaniem już od VI w. penitencjały stosowano w praktyce sądów biskupów zachodniego

${ }^{150}$ Halitgar, De vitiis, s. 292; w tej samej części biskup Cambrai zaleca nakładanie umiarkowanych w wymiarze pokut dla niewolników, gdyż „nie są oni w swojej władzy”.

151 Ibidem, ks. VI, r. 83, s. 299.

152 Pokutę „przez zastępców” kompleksowo skrytykował, punktując jej absurdalność, anonimowy autor nieco starszego penitencjału Oxoniense II - por. G. Fort, Penitents, s. 25. Tamże, s. 29 o krytyce na synodzie Kościoła anglosaskiego w Clovesho z 747 r., gdzie mowa o bogatym człowieku, który dla szybkiego odpokutowania swojego nikczemnego czynu „wykupił” sobie jałmużnami posty, które sam musiałby wypełniać przez 300 lat... - por. Council of Clovesho, 747, w: Councils and Ecclesiastical Documents Relating to Great Britain and Ireland, t. 3, wyd. A.W. Haddan, W. Stubbs, Oxford 1871, rozdz. 27, s. 373-374. Por. R. Meens, Frequency and Nature, s. 51. Zatem już przed Halitgarem zajmowano się jednak tą kwestią.

${ }^{153}$ Nie wszędzie tak było, por. T.P. Oakley, Commutations, s. 350 o penitencjałach ze stulecia Halitgara: „During the ninth century, several penitentials appeared which provided for very detailed commutations in terms of biduana, triduana, the saying of psalms or of masses, vigils, corporal punishment, genuflections, etc. Redemption of penance through the giving of alms or the payment of money was also allowed by such manuals [--] It is very noteworthy, however, that the penitentials of the ninth century put definite limitations upon the use of commutations and redemptions". Na marginesie: istnieje związek między komutacjami a późniejszym rozwojem praktyki odpustów - C. Vogel, Composition, przyp. 39 s. 300. 
Kościoła ${ }^{154}$. Odnosiły się przecież do wykroczeń publicznych. W swojej rozwiniętej postaci wykraczały poza regulowanie wymiaru i praktyki pokuty prywatnej. Określały, kiedy duchowny powinien być suspendowany lub usunięty ze stanu kapłańskiego (i w konsekwencji osadzony w klasztorze, co służyło też oszczędzeniu reputacji duchowieństwa jako całości ${ }^{155}$. Choćby tylko w tym punkcie ich wykonawcą nie mógł być nikt inny, jak tylko biskup. W IX w. zaczęły już szczegółowo opisywać procedurę (pokutne ordines). Ponieważ biskup rozstrzygał o ich stosowaniu w swojej diecezji, można je określać jako zbiory praw dla biskupiego obszaru jurysdykcyjnego.

Czy zatem penitencjały tworzone w IX w. (to znaczy: nie tylko Halitgar) służyły odmierzaniu pokuty w codziennej praktyce tysięcy szeregowych kapłanów, jak zwykło się uważać? Czy raczej funkcjonowały w kościelnych sądach, służąc pomocą w wyznaczaniu kościelnych kar, oraz w szkołach, gdzie pomagały formować nowych kapłanów, zwłaszcza tych, którym w owych sądach dane było działać? Wydaje się bowiem, że łatwo dawały się zaadaptować do obu tych celów ${ }^{156}$. Rob Meens uznawał za możliwe ich zastosowania zarówno w edukacji duchownych, jak i w sądach biskupich oraz wciąż też w roli praktycznego poradnika dla spowiedników ${ }^{157}$. Nadto pośrednio przyczyniały się one do edukacji świeckich w kwestiach moralnych, co szczególnie trudno oszacować ${ }^{158}$.

154 „Die einheitliche Anwendung der kirchlichen Strafrechts in der Diözese sollten seit der Karolingerzeit die Bußbücher garantieren. Deshalb kontrollierten und approbierten die Bischöfe deren Gebrauch durch untergebene Amtsträger, verwendeten sie vor allem aber auch selbst bei der Ausübung ihrer Gerichtsbarkeit. Als Sammlungen des kirchlichen Strafrechts waren die Bußbücher ein wichtiger Bestandteil von Handbüchern für die Diözesanwervaltung”, F. Kerff, Libri paenitentiales, s. 49-50.

155 Por. A.H. Gaastra, „Between Liturgy”, s. 195 - tu w kontekście włoskich penitencjałów, Valicellianum I, Cassinense, Vaticanum oraz problemu skandalu wywoływanego przez duchownych; o drugim etapie - po depozycji biskupa czy kapłana, czyli osadzaniu w klasztorze por. M. de Jong, Monastic Prisoners, s. 303.

156 A.J. Frantzen, The Significance, s. 420.

157 R. Meens, Frequency and Nature, s. 45. Przeciw ostrej opozycji: „pastoralny” versus ,jurydyczny” sposób użytkowania penitencjałów wypowiedziała się Erin Abraham, op. cit., s. 12. Ludger Körntgen, Fortschreibung, s. 207, nie zgadza się z tezą, że penitencjały służyły raczej biskupom niż księżom.

${ }^{158}$ R. Stone, op. cit., s. 34. W testamencie Eberharda margrabiego Friulu, powinowatego Karolingów, z ok. 863 r. wymieniony został egzemplarz penitencjału, najprawdopodobniej - Halitgara (jako „librum de utilitate poenitentiae”) - R. Kottje, Erfassung und Untersuchung der frühmittelalterlichen kontinentalen Bussbücher. Probleme, Ergebnisse, Aufgaben eines Forschungsprojektes an der Universität Bonn, „Studi medievali” 25, 1985, 2, s. 948-949; jak był wykorzystywany w otoczeniu margrabiego - nie wiadomo. 
Dla rozstrzygnięcia tych kwestii pomocne okazują się badania nad rękopisami. Jakkolwiek najstarsze manuskrypty z tekstem Halitgara pochodzą z czasu niemal nakładającego się na domniemany czas jego napisania - druga ćwierć IX w. - to w istocie zachowało się niewiele wczesnych kopii ${ }^{159}$. Można zakładać, że na początku kompilacja była rozpowszechniana głównie za sprawą Ebbona (który przeżył swojego kolegę z Cambrai). Wskazywałaby na to geografia manuskryptów ${ }^{160}$. Dzieło Halitgara stało się popularniejsze - co wyraża się w kolejnych powstających pełnych lub niepełnych odpisach - po następnych kilku dekadach. Zachowane kopie $\mathrm{z}$ tego okresu tak samo pochodzą tylko z niektórych regionów państwa frankijskiego - północny wschód dzisiejszej Francji i jego sąsiedztwo, północne Włochy ${ }^{161}$. Charakter rękopisów i różnego typu wiadomości o ich historii pozwalają stwierdzić, że większość należała do bibliotek biskupich. Dzieło Halitgara okazuje się być najpopularniejszym penitencjałem w zachowanych katalogach bibliotek; geografia owych katalogów współgra z geografią zachowanych kopii - choć oczywiście nie wszystko, co zostało wymienione w spisach, dotrwało do naszych czasów ${ }^{162}$.

Trudniej jest natomiast odnaleźć i zidentyfikować rękopisy, które mogły trafić do użytku szeregowych duszpasterzy. Jeden z powodów wydaje się dosyć prosty. Były w założeniu gorzej wykonane, z rzadka rejestrowane (rzadziej powstawały ich spisy), intensywniej eksploatowane, mniej strzeżone, łatwiej ulegały zniszczeniu. Miały dużo mniejszą szansę na zachowanie niż egzemplarze $\mathrm{w}$ miarę bezpiecznie bytujące przez stulecia w biskupich, kapitulnych czy klasztornych księgozbiorach. Zachowały się pojedyncze tego rodzaju egzemplarze - nieefektowne,

159 R. Kottje, Die Bussbücher, s. 5: najstarszy rękopis datowany paleograficzne na 825-850 r.

160 R. Meens, Frequency and Nature, s. 44 i przyp. 47 tamże, z sugestią, że rękopisy Halitgara dotarły owszem na poziom parafii; R. Kottje, Intentions- oder Tathaftung?, s. 739, przyp. 4; S. Meeder, Defining Doctrine in the Carolingian Period. The Contents and Context of Cambridge, Pembroke College, MS 108, „Transactions of the Cambridge Bibliographical Society” 13, 2005 [2007], 2, s. 147: „The ninth-century manuscript diffusion of Halitgar's penitential was heavily concentrated in north-eastern France - without doubt the result of Ebo's promotion of the handbook among his priests and bishops and somewhat less in northern Italy, possibly the result of Ebo's abbacy of Bobbio after $841 "$.

${ }^{161}$ R. Kottje, Bußpraxis und Bußritus, w: Segni e riti nella chiesa altomedievale occidentale, 11-17 aprile 1985, Spoleto 1987, s. 374, 380, 385; C. van Rhijn, M. Saan, op. cit., s. 38.

162 R. Kottje, Bußpraxis, s. 388; por. też idem, Erfassung, s. 941-951: przedstawiony tu został projekt poszukiwania penitencjałów w katalogach i inwentarzach średniowiecznych bibliotek. 
w małych formatach, z widocznymi śladami użytkowania ${ }^{163}$. Nadreprezentacja $\mathrm{w}$ grupie znanych dzisiaj i dostępnych badaniu rękopisów z penitencjałami tych zachowanych w księgozbiorach klasztorów czy katedr może zatem skrzywiać perspektywę. Nie jest sama w sobie mocnym argumentem za twierdzeniem, że tekst Halitgara miał służyć i służył - wąskiemu kręgowi duchownych z otoczenia biskupów, przy sądzeniu i przy nauczaniu. Tak samo złożona struktura całego dzieła Halitgara nie przemawia za tym, że inicjator i twórca myśleli jedynie o bardziej wyrafinowanych odbiorcach. Wolno raczej przypuszczać, że w duchu zaleceń synodalnych dążono do intelektualnego i moralnego podniesienia każdego szeregowego duchownego.

Dla określenia intencji - odrębnych, co już zresztą widać, od późniejszej praktyki - towarzyszących Halitgarowi oraz Ebbonowi przy inicjowaniu, opracowywaniu i wreszcie włączaniu w obieg sześciu ksiąg biskupa Cambrai, warto wrócić do kontekstu synodów z 813 i 829 r., do polityki Karola Wielkiego i Ludwika Pobożnego, którą episkopat karoliński oczywiście współtworzył. Reformy objęły wiele obszarów życia Kościoła. Jak zapewne pokazałby systematyczny przegląd kapitularzy i kanonów synodalnych, kolejno na agendzie pojawiały się nowe zagadnienia - wśród nich pokuta. Postawieniu problemu towarzyszyła refleksja nad stanem aktualnym: krytyczna tak od strony praktyki, jak i instrumentarium, które było w dyspozycji duchownych. Tenor cytowanych w artykule kanonów synodalnych sugerował dominację krytyki - co nie znaczy oczywiście, że wszyscy biskupi ją podzielali. Dla przekonanych natomiast do takiego poglądu - w tym właśnie Ebbona i Halitgara dalekosiężnym celem mogła się stać standaryzacja praktyk pokutnych na obszarze wykraczającym poza metropolię Reims i jej sufraganie; otwarcie mówiąc - w całym państwie Ludwika. Realizacja owego celu wymagała kompromisów. Takim kompromisem było m.in. uwzględnienie w penitencjale różnych nurtów tradycji. Duchowni - a także ich zwierzchnicy - byli bowiem z owymi nurtami względnie oswojeni. Dlatego szósta księga ma tak bardzo eklektyczny charakter.

Poprzestając niestety na hipotezach - nie zachowały się przecież żadne wypowiedzi na ten temat kościelnych dostojników, o których mowa - warto spróbować odtworzyć ich domniemany plan. Przygotowane przez Halitgara jeszcze przed synodem paryskim 829 r. lub szybko

${ }^{163}$ R. Meens, Frequency and Nature, s. 39; s. 46-47 o zachowanych rękopisach służących być może zwykłym księżom; też R. Kottje, Erfassung, s. 948-949. Sarah Hamilton, The Unique Favour, s. 234, uznaje samą większą liczebność powstałych w okresie karolińskim rękopisów z penitencjałami od tych z tekstami dotyczącymi stricte prawa kanonicznego za przesłankę ich cyrkulowania wśród kleru poza diecezjalnymi stolicami. 
po nim dzieło w pierwszej kolejności miało zostać przedstawione innym biskupom jako pomysł na regulację spraw związanych z pokutą we wszystkich diecezjach. Odpowiednim forum dla debaty stać się mogły kolejne synody. Po zaakceptowaniu treści zaleceń sformułowanych przez Halitgara na poziomie episkopatu, w pierwotnej postaci, a może z modyfikacjami, byłyby one rekomendowane i kolportowane pośród kleru parafialnego.

Owi pierwsi adresaci stanowili wymagającą intelektualnie grupę. Nurtujące ich problemy znalazły wyraz w pierwszych księgach traktatu Halitgara, w rozważaniach o cnotach i wadach. Nie chcę przez to sugerować, że miały one podrzędną funkcję wobec „rzymskiego” penitencjału i że Halitgar wręcz posłużył się tu fortelem z nadzieją na to, że ambitnym traktatem zdobędzie przychylność dla potencjalnie kontrowersyjnego w takim gronie właściwego penitencjału. Jak napisano powyżej, pierwsze księgi mogły być pomyślane w znacznej mierze jako bardzo pomocne w kształceniu duchownych. Przy czym i dla biskupiego kompilatora, i dla innych biskupów oczywista była kompleksowość zagadnienia: bynajmniej nie na zasadzie tradycji kościelnej literatury refleksja o wadach i cnotach graniczyła z rozstrzygnięciami dotyczącymi pokuty.

Osiągnięcie aprobaty dla ujednolicenia rytu i uzgodnienia miar nakładanych pokut było w warunkach roku 830 bardzo trudnym zadaniem. Należało się spodziewać silnego oporu w związku z obroną uprawnień hierarchów w zakresie tworzenia regulacji na obszarze ich diecezji. Nawet biskupi osobiście przekonani do samej idei standaryzacji łatwo mogli się stać przeciwnikami konkretnych rozwiązań, wymyślonych gdzie indziej, narzucanych przez kogoś innego. Nie byli też zapewne skłonni z takiego akurat powodu antagonizować przywiązanych do dotychczasowych praktyk (nawet jeśli nie stanowiły one regionalnie dających się wyodrębnić tradycji) duchownych ze swoich diecezji.

Halitgar i Ebbo w związku z postanowieniami synodu paryskiego (829) uznali być może, że jest dobry klimat dla próby zaproponowania całościowej regulacji. Jednak idące w stronę ujednolicenia uprzednie kościelne reformy pod panowaniem Karolingów wcielane były przy mocnym wsparciu monarchy o niekwestionowanym autorytecie. W warunkach roku 830 narastająca niestabilność polityczna, kontestacja rządów Ludwika Pobożnego pozbawiały podobną inicjatywę tego rodzaju atutu. Bez poparcia i zaangażowania cesarza nie miała szans. A cesarz Ludwik prawdopodobnie już nie mógł, a w związku z tym i nie chciał, w nią się zaangażować. W źródłach brak śladów dyskusji o traktacie Halitgara i rozwiązaniach w nim zawartych - inicjatorzy bowiem mogli bardzo szybko się zorientować, że realia polityczne $\mathrm{w}$ istocie ich planowi nie 
sprzyjają i wycofali się z jego promowania. Porażka na tym poziomie skazała Ebbona (bo Halitgar zmarł już w 831 r.) na bardziej ograniczone działania. Traktat Halitgara stał się mianowicie propozycją dla duchowieństwa metropolii Reims. I znowu turbulencje kariery samego Ebbona nie pozwoliły na bardziej stanowcze narzucanie tej propozycji.

Reformatorskie działania w dziedzinie pokuty w pierwszej połowie IX w. nie były działaniami wyizolowanymi. Zazębiały się z innymi obszarami polityki kościelnej. I nie tylko kościelnej. Synod paryski z 829 r., co najmniej pośrednio łączony z powstaniem dzieła Halitgara, piętnował grzechy biskupów, ale też świeckich. Pokuta miała stanowić środek oczyszczenia również życia politycznego. Niedługo potem Ebbo stał się jednym z liderów buntu, który doprowadził do publicznej pokuty Ludwika Pobożnego w Soissons ${ }^{164}$. Nie wdając się w szczegóły, wydarzenia potoczyły się w kierunku niekorzystnym dla arcybiskupa Reims. Co jednak zwraca uwagę, to jego inicjatywa, ażeby uzasadnić od strony prawa kościelnego działania związane z pokutą cesarza. Tekst Halitgara, powstały kilka lat wcześniej, sam w sobie nie mógł temu posłużyć. Współtworzył jednak ideologiczne tło. Działo się tak, gdyż przywoływał kościelne autorytety i zwyczaje ukształtowane przez stulecia i w ten sposób zakorzeniał w przeszłości współczesne sobie formy pokuty. W zainicjowaniu jego dzieła wyraziła się ta sama legalistyczna tendencja, jakiej Ebbo dawał wyraz w trakcie kryzysu politycznego, w centrum którego się znajdował ${ }^{165}$. Dlatego pokuta Ludwika z 833, inaczej aniżeli te z 822 i 830 r., od strony kanonicznej uchodziła za w pełni poprawnie przeprowadzoną ${ }^{166}$. Z perspektywy arcybiskupa ironią losu musiał być wszakże fakt, że penitencjał zmarłego tymczasem Halitgara wykorzystano w dyskusji nad określeniem prawnych podstaw jego własnej depozycji z tronu arcybiskupiego - jak też późniejszych prób przywrócenia do godności ${ }^{167}$.

164 O genezie tego kryzysu w ostatnich latach pisał Steffen Patzold, Eine „loyale Palastrebellion” der „Reichseinheitspartei”? Zur Divisio imperii von 817 und zu den Ursachen des Aufstands gegen Ludwig den Frommen im Jahre 830, „Frühmittelalterliche Studien” 40, 2006, s. 41-77, rozważając motywację liderów w kontekście idei synodu paryskiego 829 r., w którym część z nich brała udział. Por. też F.L. Ganshof, op. cit., s. 39-54.

${ }^{165}$ Na ten temat por. C.M. Booker, Past Convictions, s. 179-180, m.in. taka konkluzja: „Ebbo, the leader of the ritual in 833, determined to make certain that the meaning of the penance at Saint-Médard, like its later codification in the bishops' Relatio, was in accordance with ancient 'ecclesiastical custom' - custom that collections like Halitgar's were meant to make manifest". Wspomniana w cytacie Relatio to tekst, który z perspektywy rebeliantów usprawiedliwiał działania wobec Ludwika; Ebbo jest typowany jako jego autor.

166 Ibidem, s. 180.

167 R. Meens, Frequency and Nature, s. 40. 
Traktat Halitgara nie miał szans na uznanie za powszechnie obowiązujący. Powstanie kilkanaście lat później kolejnych penitencjałów „reformatorskiego nurtu" - w szczególności aż dwóch pióra Hrabana Maura też stanowi dowód. Przy czym jeśli Ebbo czy Halitgar żywili tego rodzaju ambicje - jak powyżej zostało zasugerowane - od początku nie miały one szans na spełnienie. Na przeszkodzie stała cała tradycja związana z penitencjałami - nie posiadały one przecież statusu tekstów obligatoryjnych. Co ważniejsze, w warunkach epoki głos decydujący w kwestii stosowania konkretnego penitencjału na terenie danej diecezji należał do jej biskupa. Tymczasem nie są znane zalecenia biskupów - zawarte choćby w statutach diecezjalnych - które rekomendowałyby którykolwiek penitencjał. Zdaniem Carine van Rhijn nie wynikało to bynajmniej z obojętności hierarchów w tej materii. Raczej uznawali oni, iż podlegli im kapłani dzięki edukacji nabyli wystarczających kompetencji by ocenić, jakie reguły i zasady dotyczące pokuty są właściwe. Dodatkowym skutkiem tego rodzaju podejścia było to, że akurat w dziedzinie pokuty nie wytworzyły się regionalne/lokalne odrębności ${ }^{168}$.

Ostatnie ślady walki z nieautoryzowanymi penitencjałami pochodzą z czasów krótko po Halitgarze. W 847 r. do sprawy odniósł się mianowicie synod w Moguncji. Powstawały też jednak nowe teksty. Wspomnianemu synodowi przewodniczył arcybiskup Hraban Maur ${ }^{169}$. Ów kolejny znaczący karoliński intelektualista sam opracował dwa penitencjały na różnych etapach swojej działalności. Nie ma tu sprzeczności. Brak satysfakcji i podejrzliwość w stosunku do rozplenionych ksiąg pokutnych niepewnego pochodzenia przy równoczesnym przekonaniu o nieodzowności rozstrzygnięcia tych kwestii i dostarczenia pomocy szeregowym spowiednikom wiodły do próby stworzenia czegoś nowego, o niekwestionowanym autorytecie i pretensjach do uniwersalności. Podobna motywacja stała za opracowaniem m.in. na bazie tekstu Halitgara już w ostatnich dekadach IX w. na tym samym obszarze: między Kolonią, Moguncją, Reims i Cambrai tzw. Paenitentiale mixtum. To był prawdopodobnie kolejny dowód troski biskupów o jakość ksiąg, które stosują w związku z pokutą podlegli im duchowni ${ }^{170}$. Jeszcze tylko w statutach biskupa Rodulfa z Bourges powraca ok. 850 r. ton potępienia wobec penitencjałów. A jednak jako takie - jako samodzielne, odrębne teksty - były

168 C. van Rhijn, The Local Church, s. 703; por. też s. 705: „The way in which penance was administered, [--] was a local affair depending on available texts, the priests' education and his personal assessment of the case"; o odpowiedzialności biskupów za uregulowanie pokuty w ich diecezjach F. Kerff, Libri paenitentiales, s. 30-31.

169 R. Kottje, Die Bussbücher, s. 3. 7.

170 O Poenitentiale mixtum por. L. Körntgen, Bußbuch und Bußpraxis, s. 203-207. 
one zdaniem Pierre'a Payera eliminowane z oficjalnego kościelnego prawodawstwa ${ }^{171}$. Natomiast materiał z penitencjałów zaczynał szerzej wchodzić do kolekcji o innym przeznaczeniu - tekstów wyraźnie prawniczych. Jeszcze u schyłku IX w. także zapisy z traktatu Halitgara trafiły do tego rodzaju dzieła Reginona z Prüm ${ }^{172}$.

W wiekach X i XI właściwie nie powstały nowe penitencjały. Stare kopiowano wraz z tekstami prawnymi. Kontekst jurydyczny przeważał już nad pastoralnym - w każdym razie w porównaniu z IX stuleciem ${ }^{173}$. Zaznaczyła się też tendencja do włączania materiału z penitencjałów w szersze kolekcje, niekiedy zawierające wyciągi z kilku ksiąg - to wszystko w okazałych rękopisach bez wątpienia przeznaczonych do biskupich bibliotek ${ }^{174}$. Przy czym coraz mniej chętnie sięgano w poszukiwaniu uznawanych za wartościowe źródeł po kompilacje anonimowe. Tego rodzaju nastawienie „premiowało” obdarzony autorytetem biskupiej godności kompilatora traktat Halitgara. Dowodzić to może skutecznej biskupiej kontroli nad tego rodzaju piśmiennictwem, a także troski o prawnicze (w obszarze prawa kanonicznego naturalnie) przygotowanie kapłanów w ich diecezjach. „Reformatorskie” dzieła Halitgara czy Hrabana jako usystematyzowane zbiory kanonów pokutnych służyć mogły w każdym razie szeregowym duchownym w przyswojeniu sobie prawa kanonicznego, nie tylko zaś jako pomoc w nakładaniu pokuty ${ }^{175}$.

171 P.J. Payer, Sex and the Penitentials, s. 58.

172 Por. niedawne wydanie, dwujęzyczne (z niemieckim przekładem), ale nie tekstu kompletnego: Das Sendhandbuch des Regino von Prüm / Reginonis Prumiensis Libri Duo de synodalibus causis et disciplinis ecclesiasticis, wyd. W. Hartmann, Darmstadt 2004.

173 S. Hamilton, The Practice, s. 48: „Abrupt [--] between the ninth century, when the majority of penitentials were copied for use in a pastoral context, and the tenth century when the majority of manuscripts were written for a juridical or episcopal context". Autorka pozostawia otwarte pytanie, czy wiąże się to z upadkiem standardów w duszpasterstwie X w. Por. też uwagi na temat funkcjonowania kolekcji tekstów użytecznych dla biskupów w szczególności w ich praktyce sądowej: M.R. Pauk, Odciski palców świętego Wojciecha. Kolekcja prawno-kanoniczna z kodeksu Heiligenkreuz 217 w praktyce duszpasterskiej biskupa praskiego na przełomie X $i$ XI w., w: Liber Romani. Studia ofiarowane Romanowi Michalowskiemu w siedemdziesiąta rocznicę urodzin, wyd. G. Pac, K. Skwierczyński, Warszawa 2020, s. 213-214, z powołaniem na najnowszą literaturę; omawiany przez Pauka w tymże artykule rękopis, stworzony prawdopodobnie $\mathrm{w}$ jednym $\mathrm{z}$ bawarskich skryptoriów bliżej końca X w. na potrzeby biskupów Pragi, zawiera również teksty penitencjałów karolińskich, w tym Halitgara, i jest najstarszym świadectwem ich recepcji na wschód od dawnego limesu karolińskiego - ibidem, s. 221.

174 R. Meens, Frequency and Nature, s. 47.

175 Por. „Sie erfüllten nunmehr als systematische Bußkanonessammlungen eher den Zweck, den Priester das Kirchenrecht zu vermitteln, als ihnen lediglich als leitendes Nachschlagewerk zu dienen, weshalb ihnen auch meist noch ein älteres Bußbuch oder zumindest Auszüge als Praxishilfe beigegeben waren", H. von Soden, op. cit., s. 55. 
Poczynając od Halitgara dokonywała się udana integracja materiału pierwotnie pochodzącego z penitencjałów z kanonami synodalnymi ${ }^{176}$.

Wydaje się zatem, że prawny aspekt w wykorzystaniu tekstu Halitgara stał się dominujący później. Najprawdopodobniej dla biskupa Cambrai najistotniejsza pozostawała intencja towarzysząca $\mathrm{w}$ zasadzie wszystkim wcześniejszym penitencjałom. Twórca kompilacji postarał się o dostarczenie duchownym będącym na co dzień w bezpośrednim kontakcie z wiernymi podręcznika - od razu na dwóch poziomach trudności. Pierwsze pięć ksiąg zawierało rozbudowany wykład, ale też poradnik dotyczący przebiegu pokuty. Tak zwany rzymski penitencjał miał pomóc mniej wyrobionym kapłanom.

Na koniec wskazać można trop zastosowań całkiem niezależnych od intencji Halitgara lub innych twórców tego typu dzieł. Po stuleciach tworzenia nowych zestawień z pokutnymi taryfami do głosu dochodzić mógł aspekt literacki czy wręcz antykwaryczny. To znaczy: pewna wąska grupa wykształconych duchownych mogła zacząć traktować penitencjały na sposób quasi-kolekcjonerski - zbierać, kopiować po to tylko, by posiadać w księgozbiorach to, co z pietyzmem uznali za część literackiej tradycji Kościoła. Niektóre rękopisy z penitencjałami (ale nie teksty jako takie!) powstały zatem być może w ogóle bez intencji stosowania ich w duszpasterskiej praktyce.

\section{Streszczenie}

W okresie panowania Karola Wielkiego i Ludwika Pobożnego promowana przez tych władców i realizowana we współpracy z episkopatem wielostronna reforma Kościoła objęła również obszar pokuty. Synody biskupie w pierwszych dekadach IX w. krytycznie ustosunkowały się do wykorzystywanych na terenie państwa Franków penitencjałów. Księgi te, przeszczepione na kontynent z Irlandii i Brytanii, zawierały zestawienia pokut, które duszpasterze mieli nakładać za poszczególne kategorie grzechów. Problemy, które zauważyły kościelne elity, wiązały się $\mathrm{z}$ niepewnym autorstwem penitencjałów, ich poddawanym w wątpliwość autorytetem oraz dużymi różnicami w treści. Ponieważ pełne wykorzenienie tego rodzaju dzieł w karolińskiej rzeczywistości okazało się mało realne, w IX w. podjęto próby opracowania nowych tekstów, wolnych od powyższych wad. Tego rodzaju przedsięwzięciem był penitencjał Halitgara, stanowiący szóstą księgę większego traktatu inspirowanego przez jedną z czołowych postaci czasów Ludwika, arcybiskupa Ebbona z Reims. Dzieło Halitgara w intencji twórcy oraz zleceniodawcy nie tylko miało zastąpić dawne penitencjały, lecz również kodyfikowało tryb nakładania

176 Por. R. Meens, Penitentials and the Practice of Penance in the Tenth and Eleventh Centuries, „Early Medieval Europe” 14, 2006, s. 7-9; A. Gaastra, Penitentials, s. 197. 
i odbywania pokuty, starając się rozstrzygnąć kompetencje biskupów, prezbiterów i diakonów. W części powielającej strukturę dotychczasowych ksiąg okazało się kolejną kompilacją. Wobec ograniczonych możliwości narzucenia go innym diecezjom, przy braku wsparcia w tym zakresie ze strony władzy cesarskiej, penitencjał Halitgara stał się po prostu następnym reprezentantem gatunku. Ze względu jednak na autorytet biskupiego urzędu swojego twórcy był chętnie wykorzystywany przez kolejnych kompilatorów.

\section{The Penitential of Bishop Halitgar and the Carolingian 'Penitential State'}

The comprehensive Church reform carried through under Charlemagne and Louis the Pious in collaboration with the episcopate also included penance. Episcopal synods of the first decades of the ninth century were critical of the penitentials used in the territory of the Frankish kingdom. These books, transplanted to the Continent from Ireland and Britain, contained lists of penances to be imposed by priests for particular categories of sins. Problems pointed out by the Church elites included the uncertain authorship of penitentials, their doubtful authority and significant differences in their texts. Since the total eradication of such works turned out to be unrealistic in the Carolingian reality, attempts were made in the ninth century to compose new texts, free from the above defects. One of such type was a penitential of Bishop Halitgar of Cambrai, which was the sixth book of a more extensive treatise inspired by one of the leading figures of the reign of Louis the Pious, Archbishop Ebbo of Reims. In the intention of its author and the person ordering it, Halitgar's text was not only to replace the old penitentials, but also to codify the way of imposing and performing penance, seeking to settle the competences of bishops, presbyters, and deacons. In its part duplicating the structure of the existing books, it was a compilation. Because of the limited possibilities to impose it in other dioceses and with no support from the emperor, Bishop Halitgar's penitential became simply yet another example of its genre. But due to the episcopal authority of its author, it was often used by subsequent compilers.

\section{Bibliografia}

Abraham Erin W., Anticipating Sin in Medieval Society. Childhood, Sexuality and Violence in Early Penitentials, Amsterdam University Press, Amsterdam 2017.

Angenendt Arnold, Braucks Thomas, Busch Rolf, Lutterbach Hubertus, Counting Piety in the Early and High Middle Ages, w: Ordering Medieval Society. Perspectives on Intellectual and Practical Modes of Shaping Social Relations, wyd. Bernhard Jussen, University of Pennsylvania Press, Philadelphia 2001, s. 15-54.

Anton Hans Hubert, Zum politischen Konzept karolingischer Synoden und zur karolingischen Brüdergemeinschaft, „Historisches Jahrbuch” 99, 1979, s. 55-132. 
Austin Greta, Vengeance and Law in Eleventh-Century Worms. Burchard and the Canon Law of Feuds, w: Medieval Church Law and the origins of the western legal tradition. A Tribute to Kenneth Pennington, red. Wolfgang P. Müller, Mary E. Sommar, Catholic University of America Press, Washington D.C. 2006.

Bachrach David, Confession in the Regnum Francorum (742-900). The Sources Revisited, "Journal of Ecclesiastical History" 54, 2003, s. 3-22.

Bedingfield Brad, Public Penance in Anglo-Saxon England, „Anglo-Saxon England” 31, 2002, s. 223-255.

Booker Courtney M., Hypocrisy, Performativity, and the Carolingian Pursuit of Truth, „Early Medieval Europe” 26, 2018, 2, s. 174-202.

Booker Courtney M., Murmurs and Shouts. Speaking the Conscience in Carolingian Narratives, w: Produktivität einer Krise. Die Regierungszeit Ludwigs des Frommen (814-840) und die Transformation des karolingischen Imperium, red. Philippe Depreux, Stefan Esders, Jan Thorbecke Verlag, Ostfildern 2018, s. 343-358.

Booker Courtney M., Past Convictions. The Penance of Louis the Pious and the Decline of the Carolingians, University of Pennsylvania Press, Philadelphia 2009.

Booker Courtney M., The False Decretals and Ebbo's fama ambigua. A Verdict Revisited, w: Fälschung als Mittel der Politik? Pseudoisidor im Licht der neuen Forschung. Gedenkschrift für Klaus Zechiel-Eckes, red. Karl Ubl, Daniel Ziemann, Harrassowitz, Wiesbaden 2015 (MGH Studien und Texte 57), s. 207-242.

Councils and Ecclesiastical Documents Relating to Great Britain and Ireland, t. 3, wyd. Arthur West Haddan, William Stubbs, Clarendon, Oxford 1871.

Das Sendhandbuch des Regino von Prüm / Reginonis Prumiensis Libri Duo de synodalibus causis et disciplinis ecclesiasticis, wyd. Wilfried Hartmann, Wissenschaftliche Buchgesellschaft, Darmstadt 2004.

Ebbo z Reims, Epistola Halitgario, w: MGH Epistolae 5, Epistolae Karolini aevi, t. 3, wyd. Ernst Dümmler, Berolini 1899, s. 616-617.

Fiori Antonia, Roman Law Sources and Canonical Collections in the Early Middle Ages, „Bulletin of Medieval Canon Law”, new series 34, 2017, s. 1-33.

Firey Abigail, Blushing before the Judge and Physician. Moral Arbitration in the Carolingian Empire, w: A New History of Penance, red. Abigail Firey, Brill, Leiden-Boston 2008, s. 173-200.

Fort Gavin, Penitents and Their Proxies. Penance for Others in Early Medieval Europe, "Church History” 86, 2017, 1, s. 1-32.

Fournier Paul, Études sur les Pénitentiels, cz. 4: Le livre VI du pénitentiel d'Halitgar, „Revue d'histoire et de littérature religieuses” 8, 1903, 6, s. 528-553.

Frantzen Allen J., The Literature of Penance in Anglo-Saxon England, Rutgers University Press, New Brunswick N.J. 1983.

Frantzen Allen J., The Significance of the Frankish Penitentials, „Journal of Ecclesiastical History" 30, 1979, 4, s. 409-421.

Frantzen Allen J., The Tradition of Penitentials in Anglo-Saxon England, „Anglo-Saxon England" 11, 1982, s. 23-56.

Gaastra Adrian H., „Between Liturgy and Canon Law. A Study of Books of Confession and Penance in Eleventh- and Twelfth-Century Italy" (Ph. D., University of Utrecht 2007), https://dspace.library.uu.nl/handle/1874/23216 (dostęp: 15 VIII 2019). 
Gaastra Adrian H., Penitentials and Canonical Authority, w: Texts and Identities in the Early Middle Ages, wyd. Richard Corradini et al., Verlag der Österreichischen Akademie der Wissenschaften, Vienna 2006, s. 191-204.

Ganshof François L., Am Vorabend der ersten Krise der Regierung Ludwigs des Frommen, „Frühmittelalterliche Studien” 6, 1972, s. 39-54.

Goering Joseph, The Internal Forum and the Literature of Penance and Confession, „Traditio" 59, 2004, s. 175-227.

Halitgarius Cameracensis episcopus, De vitiis et virtutibus et ordine poenitentium, tu według edycji w: Hermann Joseph Schmitz, Die Bussbücher und die Bussdisciplin der Kirche, 2, Mainz 1898 = Die Bussbücher und das kanonische Bussverfahren, s. 264-300.

Hamilton Sarah, The Practice of Penance 900-1050, Boydell Press, Woodbridge 2001.

Hamilton Sarah, The Unique Favour of Penance. The Church and the People c.800-c.1100, w: The Medieval World, wyd. Peter Linehan, Janet L. Nelson, Marios Costambeys (2. wyd.), Routledge, London - New York 2006, s. 229-243.

Hartmann Wilfried, Neue Texte zur bischöflichen Reformgesetzgebung aus den Jahren 829-831. Vier Diözesansynoden Halitgars von Cambrai, „Deutsches Archiv für Erforschung des Mittelalters" 35, 1979, s. 368-394.

Iogna-Prat Dominique, Topographies of Penance in the Latin West (c.800-c.1200), w: A New History of Penance, red. Abigail Firey, Brill, Leiden-Boston 2008, s. $149-172$.

Jong Mayke de, Ecclesia and the Early Medieval Polity, w: Staat im frühen Mittelalter, red. Walter Pohl, Helmut Reimitz, Stuart Airlie, Verlag der Österreichischen Akademie der Wissenschaften, Wien 2006 (Forschungen zur Geschichte des Mittelalters 11), s. 113-132.

Jong Mayke de, Monastic Prisoners or Opting out? Political Coercion and Honour in the Frankish Kingdoms, w: Topographies of Power in the Early Middle Ages, wyd. Mayke de Jong, Francis Theuws, Carine van Rhijn, Brill, Leiden-Boston-Cologne 2001 (The Transformation of the Roman World, 6), s. 291-328.

Jong Mayke de, Pollution, Penance and Sanctity. Ekkehard's Life of Iso of St Gall, w: The Community, the Family, and the Saint. Patterns of Power in Early Medieval Europe. Selected Proceedings of the International Medieval Congress University of Leeds 4-7 July 1994, 10-13 July 1995, red. Joyce Hill, Mary Swan, Brepols, Turnhout 1998, s. $145-158$.

Jong Mayke de, Sacrum palatium et ecclesia. L'autorité religieuse royale sous les Carolingiens (790-840), „Annales. Histoire, Sciences Sociales” 58, 2003, 6, s. 1243-1269. Jong Mayke de, The Penitential State Authority and Atonement in the Age of Louis the Pious, 814-840, Cambridge University Press, Cambridge 2009.

Jong Mayke de, Transformations of Penance, w: Rituals of Power - From Late Antiquity to the Early Middle Ages, red. Frans Theuws, Janet L. Nelson, Brill, Leiden-BostonKöln 2000, s. 185-224.

Karoli ad Ghaerbaldum episcopum epistola, wyd. A. Boretius, w: MGH, Capitularia regum Francorum, cz. 1, Hannoverae 1883, s. 244-245.

Kerff Franz, Das Paenitentiale Pseudo-Gregorii III. Ein Zeugnis karolingischer Reformbestrebungen, „Zeitschrift der Savigny-Stiftung für Rechtsgeschichte”, Kanonistische Abteilung 69, 1983, s. 46-63. 
Kerff Franz, Libri paenitentiales und kirchliche Strafgerichtsbarkeit bis zum Decretum Gratiani. Ein Diskussionsvorschlag, „Zeitschrift der Savigny-Stiftung für Rechtsgeschichte", Kanonistische Abteilung 75, 1989, s. 25-57.

Kieling Michał, Zasady ogólne dotyczace praktyk pokutnych na podstawie „Libri poenitentiales”, „Vox Patrum” 67, 2017, s. 225-240.

Körntgen Ludger, Bußbuch und Bußpraxis in der zweiten Hälfte des 9. Jahrhunderts, w: Recht und Gericht in Kirche und Welt um 900, wyd. Wilfried Hartmann, Annette Grabowsky, Oldenbourg, München 2007 (Schriften des Historischen Kollegs. Kolloquien 69), s 197-215.

Körntgen Ludger, Fortschreibung frühmittelalterlicher Bußpraxis. Burchads „Liber corrector" und seine Quellen, w: Bischof Burchard von Worms. 1000-1025, red. Wilfried Hartmann, Mainz 2000, s. 199-226.

Körntgen Ludger, Studien zu den Quellen der frühmittelalterlichen Bussbücher, Thorbecke, Sigmaringen 1993 (Quellen und Forschungen zum Recht im Mittelalter, 7).

Kottje Raymund, Bußpraxis und Bußritus, w: Segni e riti nella chiesa altomedievale occidentale, 11-17 aprile 1985, Presso la sede del Centro, Spoleto 1987 (Settimane di studio del Centro italiano di studi sull'alto medioevo, 33), s. 369-395.

Kottje Raymund, Die Bussbücher Halitgar von Cambrai und des Hrabanus Maurus. Ihre Überlieferung und ihre Quellen, de Gruyter, Berlin-New York 1980.

Kottje Raymund, Ehe und Eheverständnis in den vorgratianischen Bußbüchern, w: Love and Marriage in the Twelfth Century, red. Willy van Hoecke, Andries Welkenhuysen, Leuven University Press, Leuven 1981, s. 18-40.

Kottje Raymund, Einheit und Vielfalt des kirchlichen Lebens in der Karolingerzeit, „Zeitschrift für Kirchengeschichte" 76, 1965, s. 323-342.

Kottje Raymund, Erfassung und Untersuchung der frühmittelalterlichen kontinentalen Bussbücher. Probleme, Ergebnisse, Aufgaben eines Forschungsprojektes an der Universität Bonn, „Studi medievali” 25, 1985, 2, s. 941-951.

Kottje Raymund, Intentions- oder Tathaftung? Zum Verständnis der frühmittelalterlichen Bußbücher, „Zeitschrift der Savigny-Stiftung für Rechtsgeschichte”, Kanonistische Abteilung 91, 2005, s. 738-741.

Kottje Raymund, Überlieferung und Rezeption der irischen Bußbücher auf dem Kontinent, w: Die Iren und Europa im früheren Mittelalter, red. Heinz Löwe, Klett-Cotta, Stuttgart 1982, s. 511-523.

Lentes Thomas, Gezählte Frommigkeit, „Frühmittelalterliche Studien” 29, 1995, s. 1-71.

Libri poenitentiales / Księgi pokutne, red. Arkadiusz Baron, Henryk Pietras, WAM, Kraków 2011 (Synody i kolekcje praw, 5).

Lutterbach Hubertus, Die Bußordines in den iro-fränkischen Paenitentialien. Schlüssel zur Theologie und Verwendung der mittelalterlichen Bußbücher, „Frühmittelalterliche Studien" 30, 1996, s. 150-172.

Lutterbach Hubertus, Die mittelalterliche Bußbücher - Trägermedien von Einfachreligiosität?, „Zeitschrift für Kirchengeschichte” 115, 2003, 2, s. 227-244.

Lutterbach Hubertus, Intentions- oder Tathaftung? Zum Büßverständnis in den frühmittelalterlichen Bußbüchern, „Frühmittelalterliche Studien” 29, 1995, s. 120-143.

Matwiejczuk Paweł, Pokuta kościelna w świetle penitencjałów z terenów Francji i Italii z VIII i IX wieku. Próba rekonstrukcji rzeczywistości historycznej, w: Karolińscy 
pokutnicy i polskie średniowieczne czarownice. Konfrontacja doktryny chrześcijańskiej z życiem spoteczeństwa średniowiecznego, red. Maria Koczerska, DiG, Warszawa 2007 (Fasciculi Historici Novi 7), s. 9-89.

McKeon Peter R., Archbishop Ebbo of Reims (816-835). A Study in the Carolingian Empire and Church, „Church History” 43, 1974, 4, s. 437-447.

McNeill John T., Folk-Paganism in the Penitentials, „The Journal of Religion” 13, 1933, 4, s. 450-466.

McNeill John T., Gamer Helena M., Medieval handbooks of penance. A translation of the principal "libri poenitentiales" and selections from related documents, Columbia University Press, New York 1990 (wyd. 1. 1938).

McNeill John T., Medicine for Sin as Prescribed in the Penitentials, „Church History” 1, 1932, 1, s. 14-26.

Meeder Sven, Defining Doctrine in the Carolingian Period. The Contents and Context of Cambridge, Pembroke College, MS 108, „Transactions of the Cambridge Bibliographical Society" 13, 2005 [2007], 2, s. 133-151.

Meens Rob, Die Bußbü̈cher und das Recht im 9. und 10. Jahrhundert. Kontinuität und Wandel, w: Recht und Gericht in Kirche und Welt um 900, wyd. Wilfried Hartmann, Annette Grabowsky, Oldenbourg, München 2007 (Schriften des Historischen Kollegs. Kolloquien 69), s. 217-234.

Meens Rob, Frequency and Nature of Early Medieval Penance, w: Handling Sin. Confession in the Middle Ages, red. Peter Biller, A.J. Minnis, York Medieval Press, Woodbridge 1998 (York Studies in Medieval Theology), s. 33-61.

Meens Rob, Introduction. Penitential Questions. Sin, Satisfaction and Reconciliation in the Tenth and Eleventh Centuries, „Early Medieval Europe” 14, 2006, 1, s. 1-6.

Meens Rob, Penitentials and the Practice of Penance in the Tenth and Eleventh Centuries, „Early Medieval Europe” 14, 2006, s. 7-21.

Meens Rob, Politics, Mirrors of Princes and the Bible. Sins, Kings and the Well-Being of the Realm, „Early Medieval Europe” 7, 1998, 3, s. 345-357.

Meens Rob, Pollution in the Early Middle Ages. The Case of the Food Regulations in Penitentials, „Early Medieval Europe” 4, 1995, 1, s. 4.

Meens Rob, Reforming the Clergy. A Context for the Use of the Bobbio Penitential, w: The Bobbio Missal. Liturgy and Religious Culture in Merovingian Gaul, wyd. Yitzhak Hen, Rob Meens, Cambridge University Press, Cambridge 2009, s. 154-167.

Meens Rob, Remedies for Sins, w: The Cambridge History of Christianity, t. 3: Early Medieval Christianity, c.600-c.1100, red. Thomas F.X. Noble, Julia M.H. Smith, Cambridge University Press, Cambridge 2008, s. 399-415.

Meens Rob, Sanctuary, Penance, and Dispute Settlement under Charlemagne. The Conflict between Alcuin and Theodulf of Orléans over a Sinful Cleric, „Speculum” 82, 2007, 2, s. $277-300$.

Meens Rob, The Historiography of Early Medieval Penance, w: A New History of Penance, red. Abigail Firey, Brill, Leiden-Boston 2008, s. 73-95.

Moore Michael Edward, A Sacred Kingdom, Bishops and the Rise of Frankish Kingship, 300-850, Catholic University of America Press, Washington D.C. 2011 (Studies in Medieval and Early Modern Canon Law 8).

Mordek Hubert, Kanonistische Aktivität in Gallien in der ersten Hälfte des 8. Jahrhunderts: Eine Skizze, „Francia” 2, 1974, s. 19-25. 
Mordek Hubert, Kirchenrechtliche Autoritäten im Frühmittelalter, w: Recht und Schrift im Mittelalter, red. Peter Classen, Thorbecke, Sigmaringen 1977, s. 237-255.

Murray Alexander, Confession before 1215, „Transactions of the Royal Historical Society" 3, 1993, s. 51-81; przedruk w: idem, Conscience \& Authority in the Medieval Church, Oxford University Press, Oxford 2015, s. 17-48.

Nawracała Tomasz, Kwestia wiary w jednego Boga w perspektywie ksiag pokutnych i przygotowania do spowiedzi furtkowej, w: Wspótczesne oblicza wiary, red. Tomasz Nawracała, UAM. Wydział Teologiczny, Poznań 2016 s. 81-94 (Colloquia Disputationes 34).

Noble Thomas F.X., The Place in Papal History of the Roman Synod of 826, „Church History" 45, 1976, 4, s. 434-454.

Nostitz-Rieneck Robert von, Zum Bußbuch Halitgars von Cambray, „Zeitschrift für katholische Theologie" 20, 1896, 3, s. 566-571.

Oakley Thomas P., Alleviations of Penance in the Continental Penitentials, „Speculum” $12,1937,4$, s. $488-502$.

Oakley Thomas P., Commutations and Redemptions of Penance in the Penitentials, „The Catholic Historical Review" 18, 1932, 3, s. 341-351.

Oakley Thomas P., The Cooperation of Medieval Penance and Secular Law, „Speculum” 7, 1932, 4, s. 515-524.

Oakley Thomas P., The Penitentials as Sources for Medieval History, „Speculum” 15, 1940,2 , s. 210-223.

Paenitentiale quod dicitur Bigotianum, w: The Irish Penitentials, wyd. Ludwig Bieler, D.A. Binchy, Dublin Institute for Advanced Studies, Dublin 1963 (Scriptores Latini Hiberniae 5), s. 198-239.

Paschalis I, Epistola ad omnes Christianos ad partes Aquilonis, PL, t. 129, kol. 982984.

Patzold Steffen, Eine „loyale Palastrebellion” der „Reichseinheitspartei”? Zur Divisio imperii von 817 und zu den Ursachen des Aufstands gegen Ludwig den Frommen im Jahre 830, „Frühmittelalterliche Studien” 40, 2006, s. 41-77.

Patzold Steffen, Episcopus. Wissen über Bischöfe im Frankenreich des späten 8. bis frühen 10. Jahrhunderts, Thorbecke, Ostfildern 2008.

Pauk Marcin R., Odciski palców świętego Wojciecha. Kolekcja prawno-kanoniczna z kodeksu Heiligenkreuz 217 w praktyce duszpasterskiej biskupa praskiego na przełomie X i XI w., w: Liber Romani. Studia ofiarowane Romanowi Michalowskiemu w siedemdziesiata rocznice urodzin, wyd. Grzegorz Pac, Krzysztof Skwierczyński, Wydawnictwa UW, Warszawa 2020, s. 212-242.

Payer Pierre J., Sex and the Penitentials. The Development of a Sexual Code, 550-1150, University of Toronto Press, Toronto 1984.

Payer Pierre J., The Humanism of the Penitentials and the Continuity of the Penitential Tradition, „Mediaeval Studies” 46, 1984, s. 340-354.

Pieniądz Aneta, rec.: Mayke de Jong, The Penitential State. Authority and Atonement in the Age of Louis the Pious, 814-840, Cambridge 2009, „Kwartalnik Historyczny” 118, 2011, 2, s. 323-328.

Pierce Rosamond, The „Frankish” penitentials, w: The Materials, Sources and Methods of Ecclesiastical History, wyd. Derek Baker, Barnes \& Noble Books, Oxford 1975 (Studies in Church History 11), s. 31-39. 
Reuter Christian, Ebbo von Reims und Ansgar. Ein Beitrag zur Missionsgeschichte des Nordens und zur Gründungsgeschichte des Bistums Hamburg, „Historische Zeitschrift” 105, 1910, 2, s. 237-284.

Rhijn Carine van, „Et hoc considerat episcopus, ut ipsi presbyteri non sint idiothae”. Carolingian Local Correctio and an Unknown Priests' Exam from the Early Ninth Century, w: Religious Franks. Religion and Power in the Frankish Kingdoms. Studies in Honour of Mayke de Jong, wyd. Rob Meens et al., 2 wyd., Manchester University Press, Manchester 2016, s. 162-180.

Rhijn Carine van, Priests and the Carolingian Reforms. The Bottlenecks of Local Correctio, w: Texts and Identities in the Early Middle Ages, wyd. Richard Corradini et al., Verlag der Österreichischen Akademie der Wissenschaften, Vienna 2006, s. 219-238.

Rhijn Carine van, Saan Marjolijn, Correcting Sinners, Correcting Texts. A Context for the Paenitentiale Pseudo-Theodori, „Early Medieval Europe” 14, 2006, 1, s. $23-40$.

Rhijn Carine van, Shepherds of the Lord. Priests and Episcopal Statutes in the Carolingian Period, Brepols, Turnhout 2007.

Rhijn Carine van, The Local Church, Priests' Handbooks and Pastoral Care in the Carolingian Period, w: Chiese locali e chiese regionali nell'alto medioevo, Spoleto, 4-9 aprile 2013, Fondazione Centro italiano di studi sull'alto Medioevo, Spoleto 2014 (Settimane di studio della fondazione centro italiano di studi sull'alto medioevo, 61), s. 698-706.

Schmitz Gerhard, Die Reformkonzilien von 813 und die Sammlung des Benedictus Levita, „Deutsches Archiv für Erforschung des Mittelalters” 56, 2000, s. 1-31.

Skwierczyński Krzysztof, Mury Sodomy. Piotra Damianiego „Księga Gomory” i walka z sodomia wśród kleru, Towarzystwo „Historia Iagellonica”, Kraków 2011.

Soden Henning von, Confessio zwischen Beichte und Geständnis. Eine dogmengeschichtliche Betrachtung über die Entwicklung des Schuldbekenntnisses vom römischen Recht bis zum IV. Lateranum, (Inaugural-Dissertation zur Erlangung des Grades eines Doktors der Rechte durch die Rechts- und Staatswissenschaftliche Fakultät der Rheinischen Friedrich-Wilhelms-Universität Bonn) 2010, http://hss. ulb.uni-bonn.de/2010/2285/2285.pdf; wydanie książkowe: Confessio zwischen Beichte und Geständnis. Eine dogmengeschichtliche Betrachtung über die Entwicklung des Schuldbekenntnisses vom römischen Recht bis 1215 n.Chr., SÜDwestdeutscher Verlag, Bonn 2011.

Stone Rachel, Morality and Masculinity in the Carolingian Empire, Cambridge University Press, Cambridge 2012.

Szaciłło Justyna, Reforma liturgiczna VIII wieku w świetle kapitularzy Karola Wielkiego (miejsca i przedmioty liturgiczne), w: Sacrum. Obraz i funkcja w społeczeństwie średniowiecznym, red. Aneta Pieniądz-Skrzypczak, Jerzy Pysiak, Wydawnictwa UW, Warszawa 2005, s. 205-219.

Theodulfi [episcopi Aurelianensis] capitulare ad eosdem [sc. Presbyteros], PL, t. 105, kol. 208-224.

Timmermann Josh, Sharers in the Contemplative Virtue. Julianus Pomerius's Carolingian Audience, „Comitatus. Journal of Medieval and Renaissance Studies” 45, 2014, s. $1-44$. 
Vogel Cyrille, Composition légale et commutations dans le système de la pénitence tarifée, „Revue de droit canonique” 8, 1958, 4, s. 289-318; 9, 1959, 4, s. 341-360.

Vogel Cyrille, Les Libri Paenitentiales, Brepols, Turnhout 1978 (Typologie des Sources du Moyen Âge Occidental 27).

Wallach Luitpold, Alcuin on Virtues and Vices. A Manual for a Carolingian Soldier, „The Harvard Theological Review" 48, 1955, 3, s. 175-195.

Biogram: Michał Tomaszek, dr hab., od 2006 r. adiunkt, zatrudniony obecnie w Katedrze Historii Starożytnej i Średniowiecznej UMCS w Lublinie. Naukowo specjalizuje się w tematyce monastycyzmu średniowiecznego, historiografii klasztornej, dziejów cesarstwa Ottonów i ich następców; kontakt: michal.tomaszek@ poczta.umcs.lublin.pl.

Author: Michał Tomaszek - dr hab.; assistant professor since 2006, currently employed at the Department of Ancient and Medieval History at Maria Curie-Skłodowska University in Lublin. Scientifically, he specialises in medieval monasticism, monastic historiography, history of the Empire in the times of the Ottonians and their successors. Contact: michal.tomaszek@poczta.umcs.lublin.pl. 